\title{
Circulation of images and graphic practices in Renaissance natural history: the example of Conrad Gessner
}

Florike Egmond, Sachiko Kusukawa

\section{Summary}

Conrad Gessner's Historia animalium is a compilation of information from a variety of sources: friends, correspondents, books, broadsides, drawings, as well as his own experience. The recent discovery of a cache of drawings at Amsterdam originally belonging to Gessner has added a new dimension for research into the role of images in Gessner's study of nature. In this paper, we examine the drawings that were the basis of the images in the volume of fishes. We uncovered several cases where there were multiple copies of the same drawing of a fish (rather than multiple drawings of the same fish), which problematizes the notion of unique "original" copies and their copies. While we still know very little about the actual mechanism of, or people involved in, commissioning or generating copies of drawings, their very existence suggests that the images functioned as an important medium in the circulation of knowledge in the early modern period.

Keywords: Visual History of Science, Natural History, Conrad Gessner, Illustrations, Copying, Information exchange

\section{Introduction}

Conrad Gessner's Historia animalium is well known as a compilation of information from a variety of sources such as his correspondents as well as printed works. Indeed, Gessner frequently refers to his sources in the Histo-

Florike Egmond, Via di San Martino ai Monti 55, Rome (Kultura@fastwebnet.it). Sachiko Kusukawa, Trinity College, Cambridge, CB2 1 TQ, UK (sk111@cam.ac.uk) 
ria animalium: he mentions the names of donors of either images or information in lists of thanks at the beginning of the volumes, or, as is more usual, specifies the name, location and profession of the donor and occasionally dates of the gifts in the text about the animal concerned. This, in addition to his letters, has provided valuable information in reconstructing a considerable part of his network of naturalia exchanges. ${ }^{1}$ The role of images in these exchanges is the focus of our study here. ${ }^{2}$ While it was known that Gessner re-used illustrations that had been first printed by fellow naturalists, the majority of the original drawings on which the images of the Historia animalium were based had been missing since the seventeenth century. Exceptions were few: drawings of stones, minerals, fossils and birds connected with Gessner and absorbed into Felix Platter's albums in Basel; three or four further bird images recently rediscovered in New York; and (possibly) two watercolours with images of aquatic species in the collection of Naturalis (Biodiversity Center) in Leiden. ${ }^{3}$ The recent identification of two large albums with hundreds of sixteenth-century drawings as part of the Gessner-Platter collections has added a very large number of original images of fish and aquatic animals, beasts, reptiles, amphibians, and insects to the stock of visual sources for Gessner's printed illustrations. ${ }^{4}$ Together with the images in printed works used by Gessner, an album in Weimar of drawings belonging to Gessner's friend, Johannes Kentmann, and an album in Berlin with animal drawings by the Nuremberg naturalist-painter Lazarus Röting, this substantially augmented stock of Gessner's visual sources offers a rich and new opportunity for historians to examine how images were created, circulated and used by early-modern naturalists. ${ }^{5}$

In this article we will focus on the visual sources of fish and other aquatic animals among Gessner's illustrations. Within this category we will pay special attention to original drawings collected by Gessner, in particular to a cluster of several dozen images that originated in Italy, to the Kentmann

1 E.g. Delisle 2008; Dürling 1980.

2 Previous studies on Gessner's uses of visual resources include: Kusukawa 2010; Leemann van Elck 1935; Gmelig-Nijboer 1977; Fischel 2009 and 2010.

3 See University Library Basel, Ms K i 2 (minerals-fossils-stones); Ms K i 1 (birds). For the number of thirty-five birds from Gessner's collection we rely on Abeele 2002, here p. 38. For the four drawings of birds at New York, see Olson and Mazzitelli 2007; on the Naturalis drawings, Holthuis 1996.

4 Ms III C 22 and Ms III C 23, University Library Amsterdam, whose provenance was established in Egmond 2013. On the rediscovery of Gessner plant drawings see Leu in press.

5 See also the contribution by Philippe Glardon in the present issue. We exclude from our consideration the four drawings of fish attributed to Grosshans Thomann (and presumed to be designs for painted glass windows, possibly for Gessner) and the five small watercolours of animals made by Gessner himself, now at Zentralbibliothek, Zurich (Manuscript Department Ms. P 66; and Grafische Sammlung, Ehem. Varia Tiere I, 10). 
manuscript, the Naturalis watercolours and one folio in the Röting album. Quantitative matches and stylistic comparisons between Gessner's printed illustrations and the images in Amsterdam, Leiden, Weimar and Berlin will reveal intriguing aspects of copying and the circulation of images in the world of sixteenth-century naturalists-collectors. Textual information from these sources as well as from the correspondence that sustained the network of exchanges between naturalists underpins this analysis. Our aim is to offer further examination of the Gessner-Platter material on the one hand, and to extend on the other hand the discussion of several issues that play an increasingly important role in the visual history of early modern science. Key topics will be the circulation of scientific information by means of images; copying and creating multiple original images in the context of both collecting and research; and the critical use of images for illustrations in scientific works. All of these issues should be seen against the background of the larger question of historical ways of seeing and depicting naturalia. ${ }^{6}$

\section{The Amsterdam albums and visual sources of Gessner's fish images}

Although Gessner was probably more meticulous in referring to his sources than many other sixteenth-century scholars, it is nonetheless all but simple to understand how he constructed a body of visual material with which to work. On the one hand Gessner lists his printed sources and personal informants - ranging from classical works to the most recent scientific publications of his own period and from naturalists in far-away countries to friends and neighbours in his native Zurich. ${ }^{7}$ On the other hand, he does not differentiate between sources of major and those of minor (quantitative or qualitative) importance. Some sense of their relative importance to Gessner can only be obtained by going through all of Gessner's works, counting the number of times a person or printed source is referred to and evaluating how Gessner uses the information.

The list at the beginning of Historia Animalium IV (1558) in which Gessner thanks donors of fish images and information about aquatic creatures contains the names of 28 men. Nearly all of them were physicians, surgeons,

6 E.g. Lüthy/Dupre eds 2011; Parshall 1993; Scribner 1998; Givens/Reeds/Touwaide eds 2006; Molinari ed. 1984; Olmi/Tongiorgi Tomasi/Zanca eds 2000.

7 Information from Italy reached Gessner in the form of texts or images, but also as naturalia themselves. These could even be live specimens, in what were presumably exceptional cases; the Veronese apothecary and naturalist Hieronymo Calzolari sent a live animal (possibly a skink) to Gessner in Zurich. See Salzmann 1959, here p. 97 (his source, Gessner writing to Kentmann). 
or apothecaries. Geographically they could mainly be found in three parts of Europe outside Switzerland: England, Italy, and Germany, with a rather important contingent in Strasbourg in the Franco-German border zone. Among them we find men such as the British naturalist William Turner (1508-1568), the Italian mathematician Girolamo Cardano (1501-1576), the British physician-naturalist John Caius (1510-1573), the Italian physician to three Habsburg emperors Giulio Alessandrini (1506-1590), the German physician and astrologer Achilles Pirmin Gasser (1505-1577), the German historian and poet Georg Fabricius (1516-1571), and the British bishop John Parkhurst (1511-1574). Special distinction by means of a slightly longer entry is accorded only to Cornelius Sittardus "of fond memory, an excellent physician at Nuremberg a few years ago, who for the many things that he contributed, declared that he had received them all from Gysbert Horstius, a physician at Rome who lately (as I have heard) passed away, and wished all the honour to go to him rather than to himself"; further down the list, a brief entry names "Johannes Kentmann, a very noble physician in Meissen". ${ }^{8}$ Horstius, Sittardus, and Kentmann will be key figures in our story.

Many of the images given to Gessner are found in the two Amsterdam albums, which together comprise 369 sheets; 235 images on these sheets (which generally show two or three images per sheet) match illustrations in Gessner's printed works on fish. The aquatic album, with 225 sheets, has 159 matches with Gessner's printed illustrations. The percentage (but not the actual number) of matches with printed illustrations by Gessner is considerably higher for the album containing images of viviparous animals than for the fish album: 76 out of 137 (i.e. slightly more than half) of the Gessner's printed illustrations of viviparous animals match images in the Amsterdam album; 159 out of a total of 524 (i.e. just under a third) of Gessner's printed fish illustrations match the Amsterdam drawings. ${ }^{9}$

The reason for this disparity is directly related to Gessner's use of visual sources. While there were few contemporary publications of viviparous animals, aquatic animals were the subject of major studies by contemporaries of Gessner that appeared shortly before his own fish books of 1558 and 1560 . The Libri de piscibus marinis (1554/5) by Guillaume Rondelet (1507-1566), whom

8 "felicis memoriae, medicus ante paucos annos Norimbergae excellentissimus: qui tamen pro plurimis illis quae contulit, a Gysberto Horstio medico Romae nuper (ut audio) defuncto, accepisse se omnia confessus in illum potius quam sese omnem honoris gratiam conferre voluit". Gessner 1558, [b5]r.

9 For fish and aquatic animals we also refer to Gessner 1560a. For the viviparous animals we have consulted Gessner 1551, the addenda in Gessner 1554, and the additional images in Gessner 1560b. Insects, amphibians and small creatures like shells are not included in these counts. For more details see Egmond 2013 above. 
Gessner had visited in $1540,{ }^{10}$ forms an important backbone to Gessner's volume of fishes, as the latter reproduced extensively not just Rondelet's textual description but also the woodcuts. ${ }^{11}$ Each entry on a fish, if mentioned previously by Rondelet, has the latter's name added to it, and Gessner very frequently quotes Rondelet's description verbatim - sometimes these quotations stand alone as sufficient description for a particular fish; at other times they are collated with information from other sources. Rondelet's woodcuts were most probably cut out, glued or traced onto a woodblock which was then cut, since the images copied from Rondelet are consistently reversed in the Historia animalium (figs 1a and 1b). ${ }^{12}$ Over half of the woodcuts in Gessner's volume on fishes are copied from the woodcuts in Rondelet's De piscibus marinis. ${ }^{13}$ This represents over $80 \%$ of the images in Rondelet's book, and even where a woodcut is not reproduced, Gessner often refers to it, or makes a comparison with another image he had decided to use. Gessner's engagement with Rondelet's textual description is even more extensive, and it is therefore important to note that the whole of Rondelet's book forms a foundation for Gessner's volume on fishes, which is in fact acknowledged in the title page of the volume. The flow of information and images was not onesided, however, as Rondelet acknowledged Gessner's offer of help regarding fishes of the Danube and noted the images sent to him by Gessner. ${ }^{14}$ On one occasion, Gessner had sent an image of a salted "Rheinfish" from Frankfurt, which Rondelet had identified as a "Silurus", which Gessner in turn disputed..$^{15}$ While we are mainly concerned with the sources of Gessner's images, it is important to note that Gessner himself often sent out images to his colleagues.

Another work acknowledged on the title page of Gessner's volume on fishes was Pierre Belon's De aquatilibus (1553). Images from Belon's book account for about $5 \%$ (31) of the printed images in Gessner's fourth volume of Historia animalium. This comprises just over $15 \%$ of the images in Belon's

10 Wellisch 1975, here pp. 157-58.

11 Gessner's copy of this book appears not to have survived; see Leu/Keller/Weidmann eds 2008. For the importance of Rondelet's work in the seventeenth century, see Lewis 2012.

12 Note, however, that there were exceptions to the left/right inversion, for example, the images of the "leone" in Gessner 1558, 196 and Rondelet 1554/5, vol. 1, 542.

13 Of the 664 images in Gessner 1558 (inclusive of the molluscs, crustaceans and zoophytes) at least 364 may be found in Rondelet's work. On the links (especially personal and textual) between Gessner, Rondelet, Belon and Salviani and their publications on fish, see esp. Glardon 2011.

14 Rondelet 1554/5, vol. 1, 423 (for fishes of the Danube), 180 (picture of 'Balaena vera'); Rondelet 1554/5, vol. 2, 186 (on the glanis) mentions that he received the picture from a learned good man ('bono doctor viro') without spelling out his name, but this was most likely Gessner, as pointed out at Gessner 1558, 457.

15 Rondelet 1554/5, vol. 2, 182, Gessner 1558, 111. 


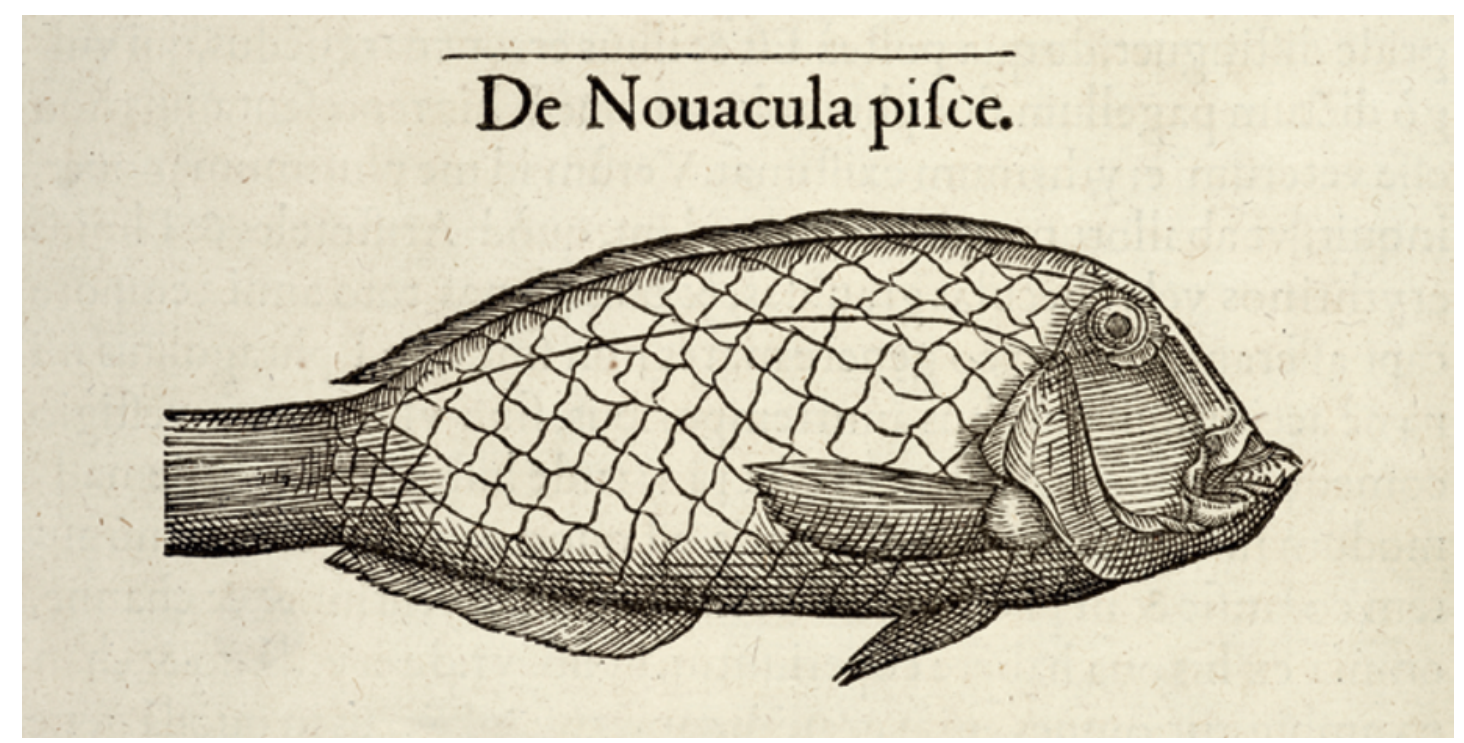

Fig. 1a: Novacula. Rondelet, Libri de piscibus marinis I (1554), 146. (Reproduced by kind permission of the Syndics of Cambridge University Library, shelfmark M.14.21.)

De aquatilibus. Gessner cites more frequently Belon's textual descriptions which are often compared closely to Rondelet's, and it appears that Gessner saw Belon's study as supplementing Rondelet's book which was more comprehensive and thus more useful for him. Gessner also copied twenty-six images, mainly sea monsters and cetaceous creatures from Olaus Magnus's Carta Marina and his book on the Northern regions, Historia de gentibus septentrionalibus, earumque diuersis statibus, conditionibus, moribus (1555). ${ }^{16}$ Gessner evidently had access to Hippolito Salviani's Aquatilium animalium historiae liber primus, cum eorundem formis aere excusis (1554-8), as he mentions some of Salviani's descriptions and pictures, but his engagement with this work is much more limited than with those of Rondelet or Belon. ${ }^{17}$

The process of identifying Gessner's sources within the Amsterdam albums is not yet completed, and the number of 159 matches (about 25\%) with illustrations in Gessner's fish book may slightly increase. This is partly because the category of small shells, which are very hard to match with their black-and-white printed counterparts, has so far been left out of our account. More importantly, the original drawings collected by Gessner and used as

16 Gessner 1558, 118, 137-139, 246-249, 483, 854, 941, 1040, 1290-1291.

17 For example, Gessner 1558, 1260, 1264, 1283. Since the printing of Salviani's work started (possibly in his own house in Rome) in 1554 but was not finished until 1558 (also on account of the use of a different press for the copper engravings), one wonders how much time Gessner actually had to see this work before his own fishbook was being printed. On the Gessner-Salviani-Belon connection, see also Glardon 2011, esp. pp. 106-109. For Salviani, see Pinon 2002. 


\section{DE NOVACVLA PISCE, RONDELETIVS,}

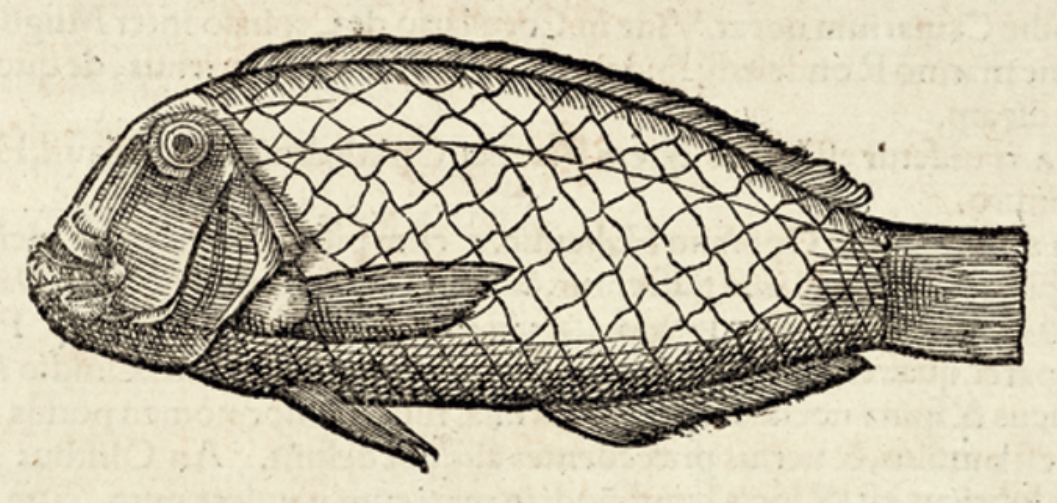

Fig. 1b: Novacula. Gessner, Historia Animalium IV (1558), 741. (Reproduced by kind permission of the Syndics of Cambridge University Library, shelfmark M.13.9.)

templates or Vorlagen for his printed illustrations are "hidden" among the hundreds of images contained in these albums. This follows from the nature of the collection itself. The albums were created some thirty years after Gessner's death (i.e. c. 1595-1614) by his correspondent and younger colleague Felix Platter (1536-1614), physician-anatomist, naturalist, and collector in Basel. ${ }^{18}$ Platter had acquired animal drawings collected by Gessner after the latter's death and used them as the core of his own collection of naturalia. He cut out nearly all of the images along the outlines of the animals, pasted them on large sheets of paper, and personally annotated most of them. In the course of his life Platter himself added many other drawings of animals: probably a third to perhaps as much as half of the images now in the albums. He mixed all of the drawings and ordered them by category: e.g. for the aquatic animals, salt water fish, fresh water fish, flat fish, crabs and lobsters, shells, etc. Some clusters of drawings can be distinguished which appear to have been created by the same artist or to have come from one donor, but these are only rarely grouped together in the albums. ${ }^{19}$

18 For Platter, see Lötscher 1975; Landolt 1972; Huber 2003; Jennett ed. 1961; and Rytz 1933. 19 The only case in which a cluster is indeed grouped together concerns twenty seven drawings of fish, which are exceptional too because of the fact that they are not cut out along the contours of the fish and have a background, and that the labels with the names of the fish in Dutch and German are part of the drawings themselves; they seem to have originated in Cologne. These drawings were not sources for Gessner, however, and probably are additions by Platter. See Ms III C 22, 157-167. A large cluster of fish drawings originating in Verona is stylistically consistent, but these drawings are not grouped together; they too are probable additions by Platter and have no matches among Gessner's printed illustrations. 


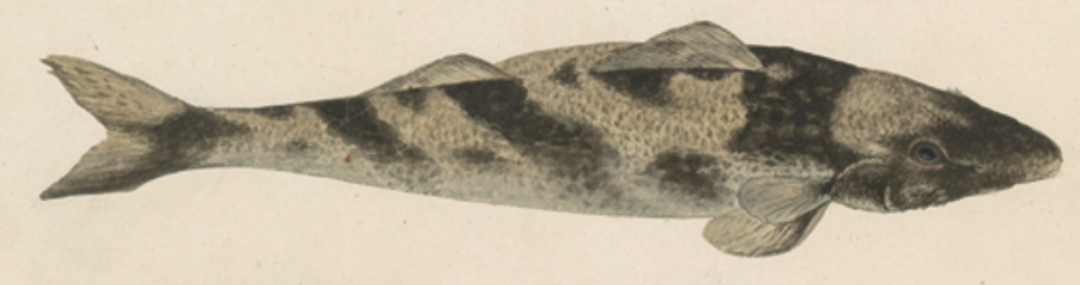

Fig. 2a: Asper/Zindel, Ms III C 22, 39, rotated clockwise for better comparison with Fig. 2b. (Amsterdam University Library)

There are only two ways, therefore, in which Gessner's Vorlagen (dating from before 1565) can be distinguished from Platter's later additions - a step that is essential if we want to investigate circulation, provenance, artists, sources, and use. ${ }^{20}$ The first is by visual similarity: if a drawing in the albums very closely matches a printed illustration by Gessner, and especially if the latter is reversed with respect to the former, we can be certain that the drawing belonged to Gessner and was a Vorlage. The second is by means of Platter's annotation, which is always in Latin or German, often consists of no more than the name of the animal, and is never more than four or five short lines in length. Platter generally copied information about gifts, donors, and dates from Gessner's printed works, immediately next to the cut-out and pasted image, which reinforces the close link between the image and its provenance.

The case of the fish Asper from the Danube is an example of how visual and textual information in the Amsterdam album and Gessner's printed work match. Platter's annotation mentions that the fish was called Zindel in German and that the image had been sent to Gessner by the imperial physician Giulio Alessandrini (figs $2 \mathrm{a}$ and $2 \mathrm{~b}$ ). Gessner himself tells us that the picture of this fish had been given him by the learned "Iulius Alexandrinus", personal physician of Emperor Ferdinand I, and that the image sent to him was 12 digitos long, which - as he had heard - was about the average length of this fish. He describes the colour of the fish and its black spots in some detail, but says that although the fish is reported to have pointed dorsal fins, the

20 Identification of the artist is only rarely possible. Only one artist's monogram has been found. The cutting out may have removed many others. Information concerning artists in the annotation combined with stylistic similarities thus far has lead to the artist's identification of only a dozen or so images. The lifetimes of Platter and Gessner overlapped, moreover, so only artists who definitely worked after Gessner's death can be excluded as makers of Gessner images. In general identification of the artists here has to follow that of the collectors, and not vice versa. 


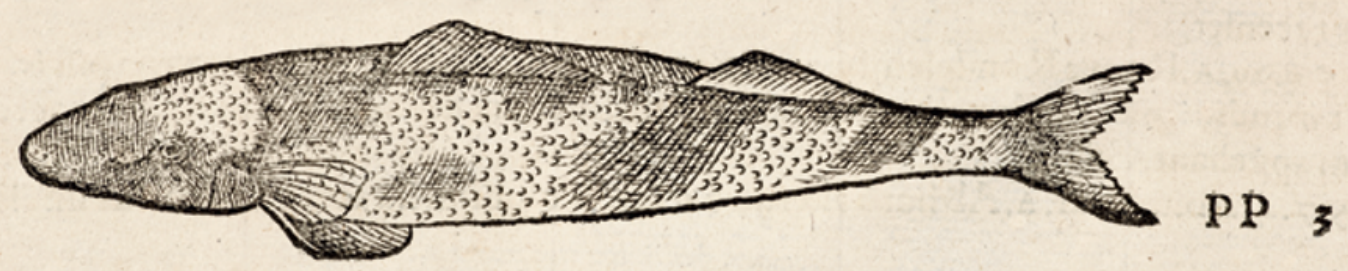

Fig. 2b: Asper/Zindel, Gessner, Historia Animalium IV (1558), 1277. (Reproduced by kind permission of the Syndics of Cambridge University Library, shelfmark M.13.9.)

picture shows it with softer, more rounded ones. ${ }^{21}$ In the case of the swordfish Gessner's comments are more critical. While Platter's annotation says "Gladius Xiphias from Caius from England. The painter left out some fins", Gessner explains that the head of the swordfish had been depicted in print after the image Caius had sent him, but the body and tail according to Rondelet. The Amsterdam image (the one Caius had sent) indeed matches the printed image only from the tip of the sword down to the gills (figs $3 a$ and $3 b$ ). ${ }^{22}$

In some exceptional cases, however, Platter appears to offer more information than Gessner's printed text, which suggests that Platter may have had more information about Gessner's legacy and work than has been realised. We will come back to these below. Here we will first concentrate on the largest cluster with a shared provenance thus far identified within the Amsterdam Albums and Gessner's printed works: almost 40 images made in Rome that reached Gessner via the above-mentioned Cornelius Sittardus.

\section{The Horstius-Sittardus images and their connection with the Naturalis watercolours}

In the course of the 1960s and 1970s the Dutch carcinologist L.B. Holthuis (1921-2008) acquired two original watercolours of fish and other aquatic animals from a British dealer. ${ }^{23}$ The first one shows one animal: the slipper lobster or squillus latus, which fills the entire sheet (fig. 4a). On the second one (fig. 4b) six figures (astaci species, the egg case of a ray; urtica marina species;

21 Ms III C 22, 39; "Icon ad me missa, digitos xii. longa est: quam longitudinem in hoc pisce mediocrem esse audio"; Gessner 1558, 1277 (image), 1278 (text).

22 “Gladius Xiphias à Caio ex Anglia Pictor pinnas aliquot omisit”, Ms III C 22, 100. Cf. Gessner 1558, 452.

23 Holthuis 1996. 


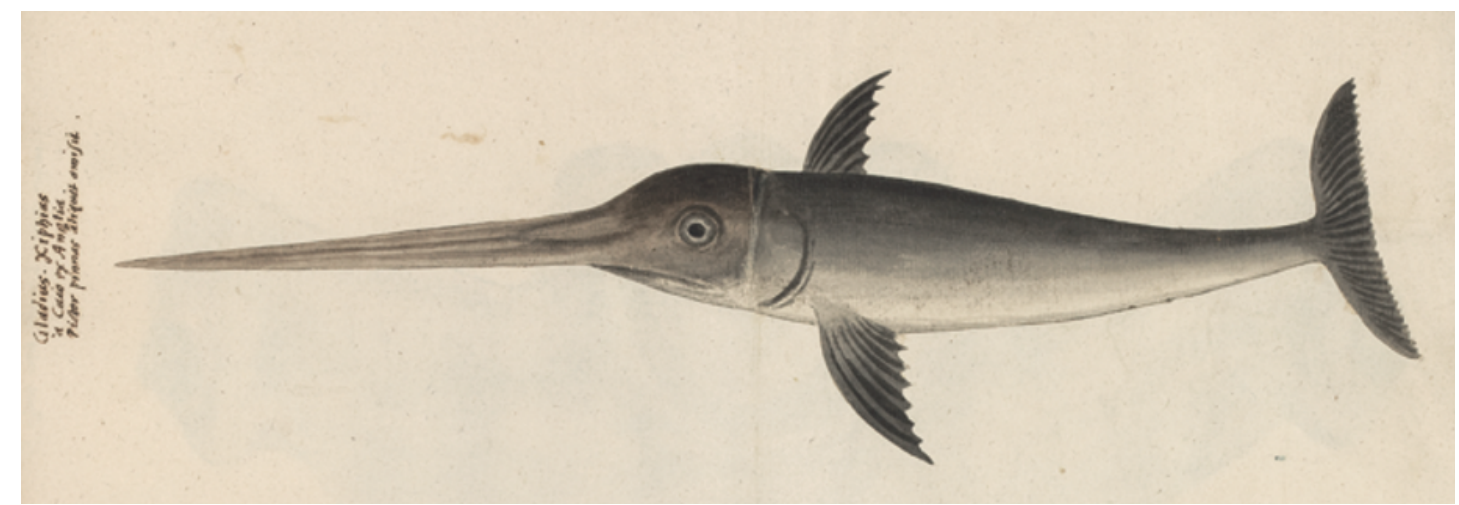

Fig. 3a: Caius' swordfish, Ms III C 22, 100, rotated anti-clockwise. (Amsterdam University Library).

\section{DeAquatilibus.}

Gladij pifcis roftrum expreffum eft, ad figuram à Ioan, Caio Anglo nobis miffam (cuius defcriptionem in Corollario pofuimus, ) corpus reliquum ut à Rondeletio exbibitum eft.

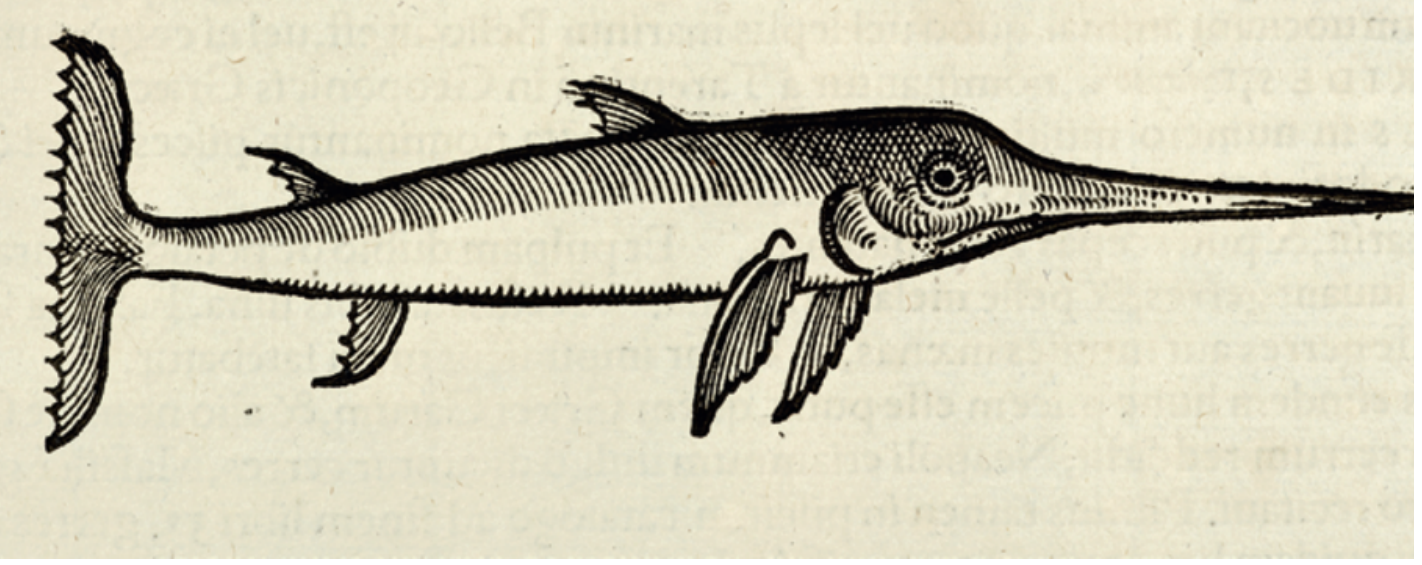

Fig. 3b: Gessner's printed swordfish. Gessner, Historia Animalium IV (1558), 452. (Reproduced by kind permission of the Syndics of Cambridge University Library, shelfmark M.13.9.) 


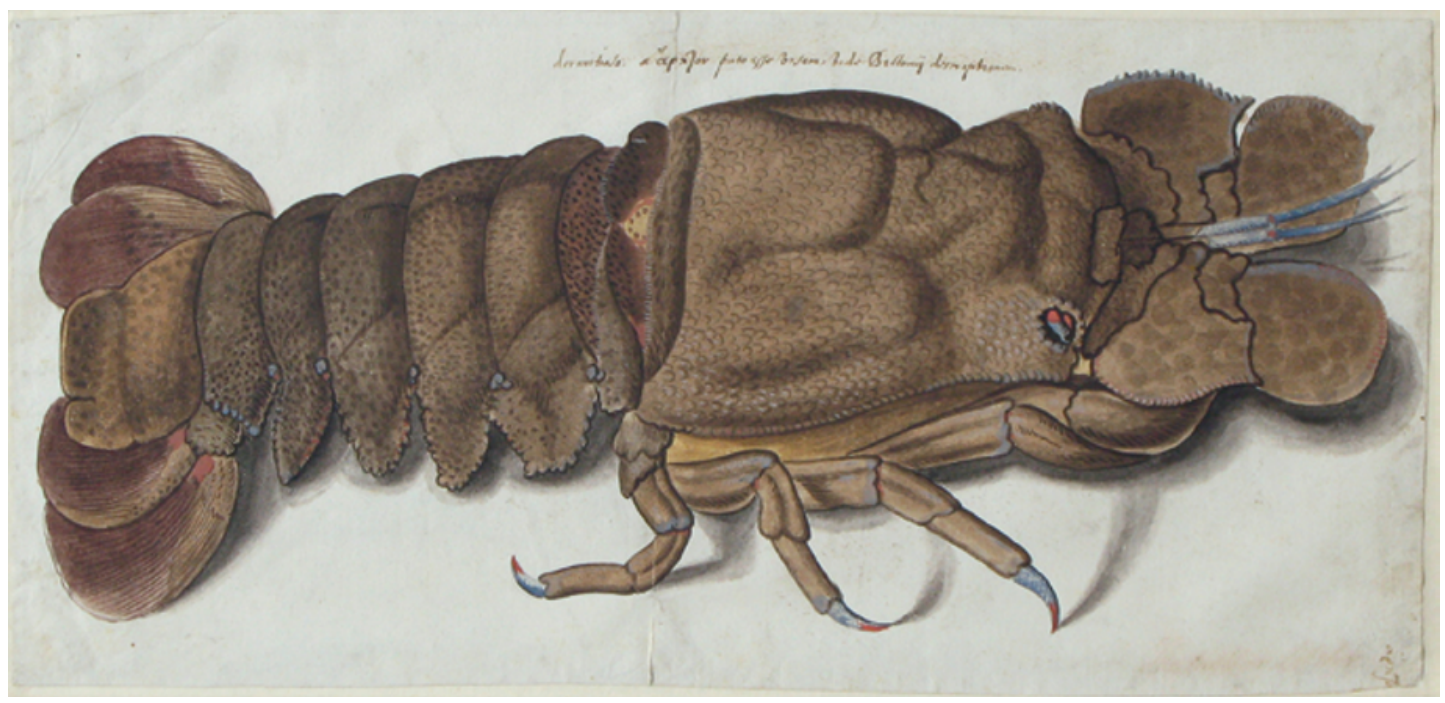

Fig. 4a: Holthuis's watercolour of the slipper lobster or squillus latus. (Naturalis, Biodiversity Center, Leiden)

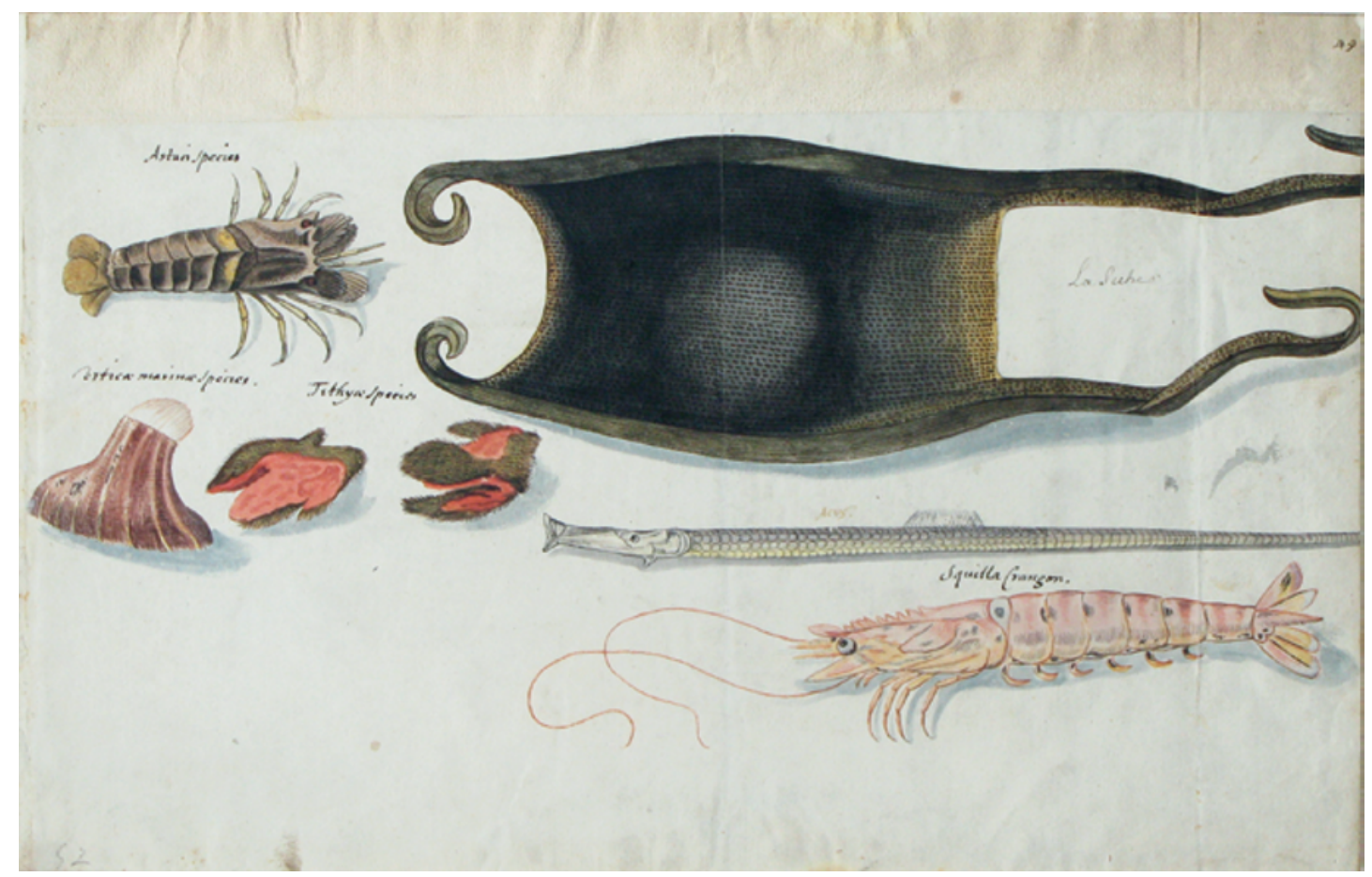

Fig. 4b: Holthuis's watercolour with six figures: astaci species, the egg case of a ray; urtica marina species; tethya in two images; acus; and squilla crangon. (Naturalis, Biodiversity Center, Leiden) 


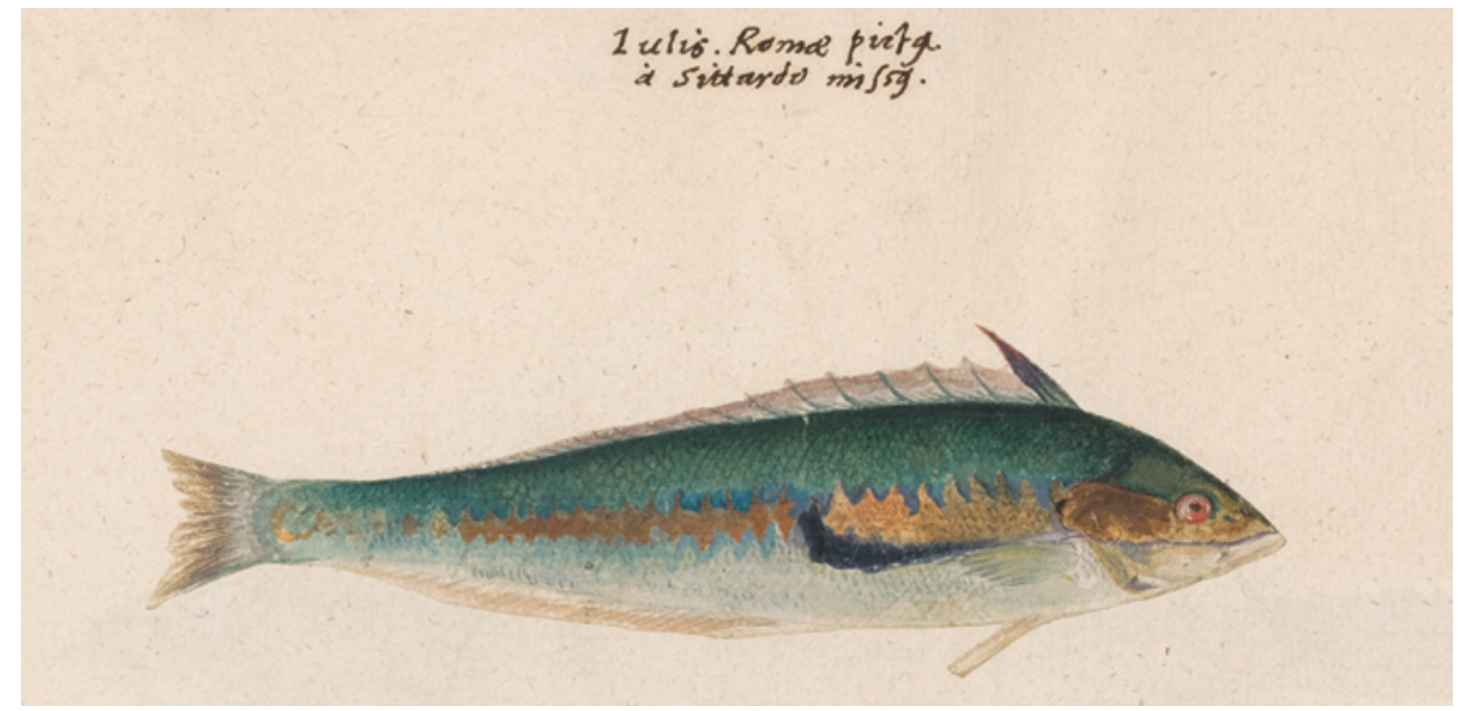

Fig. 5a: Iulis. Ms III C 22, 62 (top). (Amsterdam University Library)

tethya in two images; acus; and squilla crangon) are somewhat erratically distributed, leaving one corner empty. Neither drawing presents the animals in a setting or against a background, but the shading gives them some depth. The drawings are detailed and the colours lifelike though slightly faded. All but one of the animals depicted closely match Gessner's printed illustrations, which are reversed. ${ }^{24}$ Holthuis concluded that his two watercolours were the original models for Gessner, who wrote that those figures had originated in Rome and had reached him via Cornelius Sittardus and Gysbertus Horstius. ${ }^{25}$ Proceeding on the basis of further references by Gessner, Holthuis reconstructed a much larger group with the same provenance (31 in all, including the animals shown on his two watercolours), but of which no original drawings were thought to be extant. ${ }^{26}$

Those originals emerged in the Amsterdam albums only a few years after Holthuis' death. They contain all of the model drawings for the animals listed by Gessner (and Holthuis) as Sittardus-Horstius gifts, except one holothurius and one creature (a pediculus marinus) that was in fact an insect and not a fish. ${ }^{27}$ Platter's annotation, moreover, enables us to identify drawings of six

24 The only exception is the "astaci species" in the top left corner of the second watercolour, which cannot be found in Gessner.

25 At this moment we cannot tell how old they are except (without any precision) by means of the seventeenth- or late sixteenth-century handwriting on them.

26 Holthuis 1996. Holthuis left the drawings to Naturalis Biodiversity Center in Leiden.

27 We have some doubts about the egg case of the ray. This image is present in the Amsterdam albums (III C 22, 121) and matches the Holthuis image in every detail, but both drawings differ in some respects from the first printed illustration by Gessner of a similar egg case. The latter occurs for the first time in the German edition of Gessner's fish volume, Gessner 1563, p. LXXIIII. 


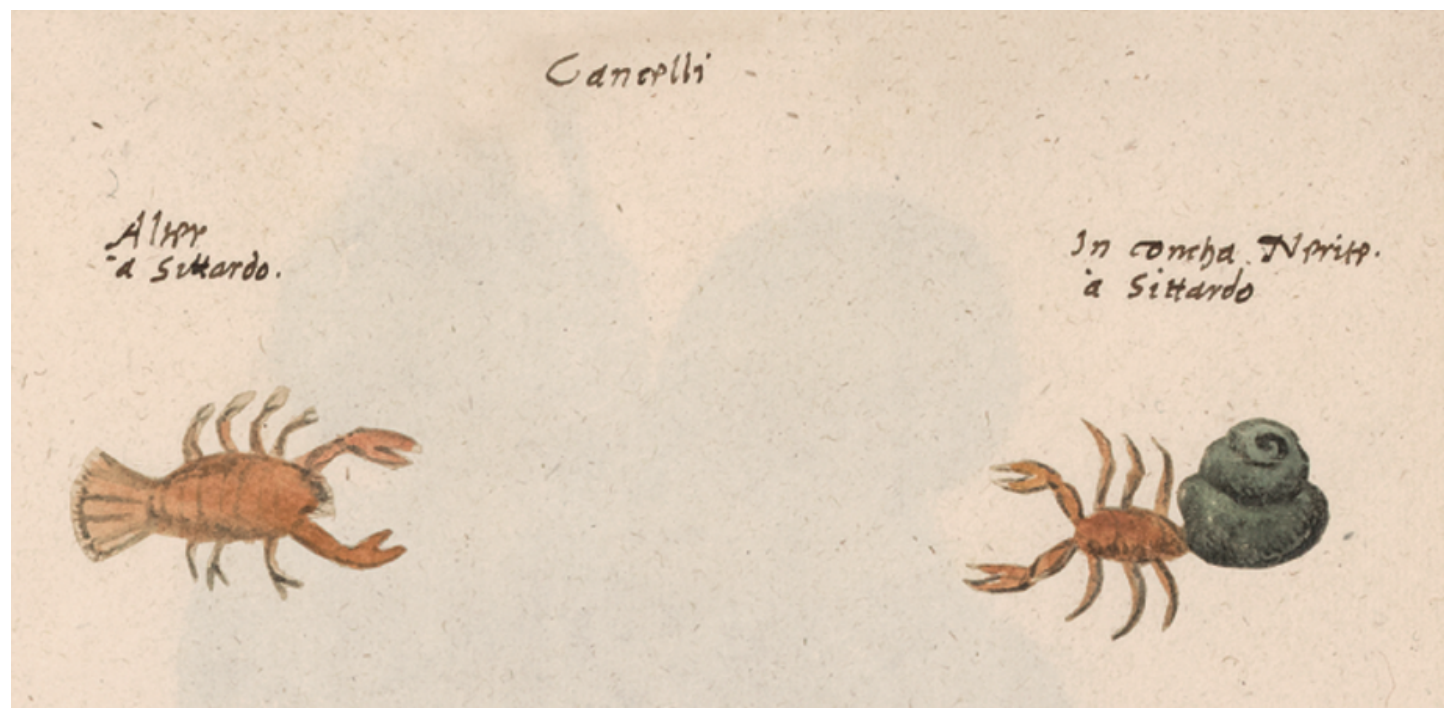

Fig. 5b: Small crayfish. Ms III C 22, 203 (top). (Amsterdam University Library)

additional creatures (iulis ${ }^{28}$ (fig. 5a), donsella ${ }^{29}$, milvus lucerna ${ }^{30}$, mullus barbatus $^{31}$, and two small crayfish (fig. 5b) ${ }^{32}$ ) as belonging to the same Roman Sittardus-Horstius cluster, which now comprises a total of 37 images.

Although Platter's annotation confirms Holthuis's identifications, it does not reveal many details about the origins of these images or about Sittardus' role. Platter's brief captions range from "a Sittardo" ("from Sittardus") to "Romae factus Corn. Sittardus misit" ("made in Rome, Cornelius Sittardus sent it") and "Romae picta à Corn. Sittardo Roma missus" ("painted in Rome, sent by Cornelius Sittardus from Rome"). ${ }^{33}$ Gessner's own text about the beautiful stromataeus fish (Stromateus fiatola) throws slightly more light on how the original drawing of this fish reached him (figs 6a and 6b). After explaining that he had chosen not to re-use Belon's image of the same species, he continues,

We have shown here the picture received in the past from Cornelius Sittardus together with other fish depicted at Rome (...) The most learned Sittardus wrote the following about it to me: This fish is commonly called Fetolo, or lampeca by the Romans (...). He also sent a picture of one which was one or two digitos longer than the one we show here. ${ }^{34}$

28 Ms III C 22, 62 (top): iulis; cf. Gessner 1558, 549.

29 Ms III C 22, 63 (top): donsella. See fig. 15a below.

30 Ms III C 22, 87: milvus lucerna. See fig. 15 b below.

31 Ms III C 22, 88: mullus barbatus. See fig. 8c below.

32 Ms III C 22, 203 (top left): small crayfish; cf. Gessner 1558, 193, bottom right; and Ms III C 22, 203 (top right): small crayfish; cf. Gessner 1558, 193, bottom left.

33 See (in that order) Ms III C 22, 18, 110, and 62.

34 Gessner 1558, 1110: "A nobis posita pictura, quam a Cor. Sittardo cum aliis piscibus Romae depictis olim accepi, (... ) De ea doctissimus Sittardus sic ad me scribebat: Hic piscis Fetolo vulgo dicitur, Romanis lampeca, (...) nec excedit hanc magnitudinem. Erat autem missa ab eo pictura, uno alterove digito longior, quam a nobis hic proposita est". 


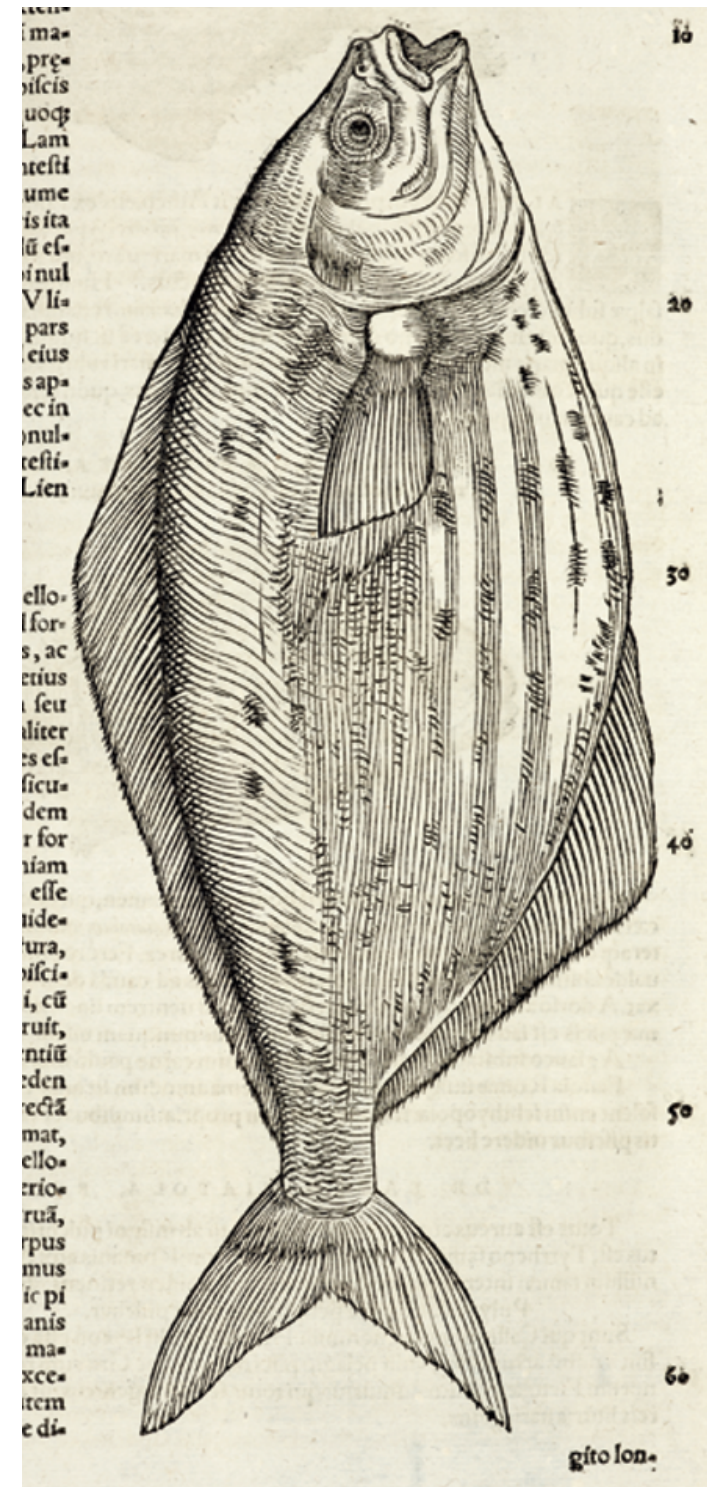

Fig. 6a: Gessner's stromataeus. Gessner, Historia Animalium IV (1558), 1110. (Reproduced by kind permission of the Syndics of Cambridge University Library, shelfmark M.13.9.)

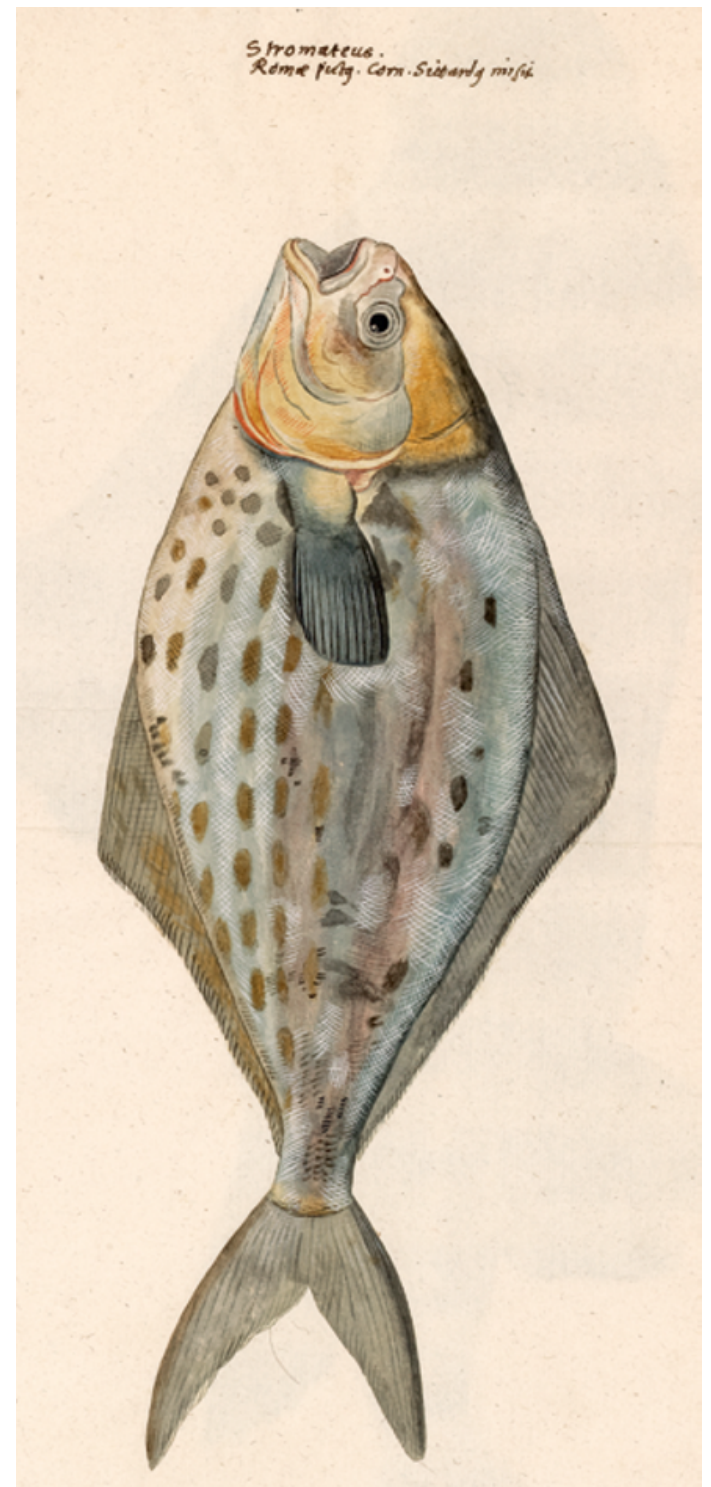

Fig. 6b: Gessner's stromataeus image from Rome. Ms III C 22, 110. (Amsterdam University Library)

Gessner's regular use of the terms "sent" and "wrote" when referring to Sittardus' gifts of images suggests that many or perhaps even all of these thirty-odd Roman fish drawings were sent him from Rome by Sittardus perhaps even as one group - rather than personally handed over to him by Sittardus. The two men may actually never have met in person. ${ }^{35}$

35 Sittardus's name is not found in Gessner's liber amicorum, though given the date from which it was compiled (1555), this does not necessarily rule out the possibility that the two had met; see Dürling 1965. 
As suggested above in Gessner's own list of thanks to donors of fish figures, Sittardus should be regarded first and foremost as an intermediary, albeit a very learned one who was interested himself in naturalia, between Gessner and the actual source of the images, Gysbertus Horstius in Rome. Glimpses of the lives of these two erudite physicians allow us a tentative reconstruction of when Gessner's Roman images were created and how they circulated. Cornelius Sittardus (c. 1500-c. 1550/51) was a German physician in Nuremberg. He was born in or near Cologne and received his first training as a physician in Germany. By 1533-44 he was studying medicine in Northern Italy. It is probably there, in Padua or Bologna, that he joined another young German physician and naturalist, Valerius Cordus (1515-1544), who was reputed to be one of the most promising young botanists of his time. During the summer of 1544 Sittardus, Cordus, the German physician and astronomer Hieronymus Schreiber (d.1547), the Dutch physician Pieter van Foreest (1521-1597; later personal physician to Prince William of Orange), and a few more young physicians from North of the Alps, travelled on foot from Northern Italy to Rome, botanizing on the way. They reached Rome in September 1544, where Cordus died shortly afterwards; some of his writings were posthumously published by Gessner. ${ }^{36}$ Cordus and Sittardus evidently observed aquatic animals together - in one case, Sittardus reported how they both found it difficult to dislodge crabs from their shells. ${ }^{37}$ In Rome, Sittardus, Foreest, and most probably the other members of this group met Gysbert van der Horst from Amsterdam (c.1491-1555/1556). ${ }^{38}$ The latter may have studied medicine in Italy as well, but had already been working for several years in Rome by this time, and was one of the two senior physicians (medico fisico) at the hospital of Santa Maria della Consolazione. Situated next to the Forum Romanum, it was surrounded at the time by many building sites and close to the housing of the middle and poorer classes of the city that was beginning to expand again. The hospital specialized in trauma care, such as stab wounds, accidents, and broken bones, and had a separate section for women, besides its own dispensary and apothecary, a garden with a professional gardener where both exotic plants and herbs were grown, and

36 See Cordus 1561, edited by Gessner. For Schreiber's description of Cordus's last days, see Cordus 1563. See also Adam 1620, 43.

37 Gessner 1558, 193; this is a rare case where we can confirm that Sittardus's figures were made from his own observation.

38 Horstius was buried in the church of Santa Maria in Trastevere, where his marble plaque in the floor remained until the late eighteenth century. Its text was: D.O.M. Gisberto Horstio Amsterodamo Medico Praecellentiss. Livia Seccocia marito suo indulgentiss. poss. Viii Kl. Mart. MDLVI. Vix. Anno LXIV. m. x. d. xii. See Alveri 1664, 340. 
a distillery where those herbs were converted into medicine. ${ }^{39}$ Horstius' only published work, De Turpeto et Thapsia (1544) deals, appropriately, with the composition and efficacy of certain poultices to treat wounds. ${ }^{40}$

Horstius worked at this hospital from c. 1543 until his death in c. 1556 (at the age of 64). He was considered one of the outstanding doctors in Rome, and also treated "private patients" outside the hospital. According to Pieter van Foreest, Roman ladies came to Horstius for concoctions to lose weight and bleach their hair as well as for recipes for cosmetics; men came for a remedy against baldness. But Horstius was apparently also required to put together poisonous potions for convicts condemned to capital punishment. Such a combination of activities was by no means unusual at the time, and the writings of his fellow physicians leave no doubt that Horstius was a highly respected and very learned man, a great expert on poisons, and a man with wide-ranging knowledge in the domain of natural history. In the hospital garden Horstius kept serpents, which he handled with great confidence (he saved his son by a quick intervention after the latter had been bitten by one of the poisonous snakes), and it is possible that he himself was involved in the growing of the exotic plants. ${ }^{41}$

Rome was still a relatively small city at the time in a phase of reconstruction and recovery after the Sack of Rome in $1527 .{ }^{42} \mathrm{It}$ is therefore almost impossible to think that Horstius would not have personally met and been in contact with the resident naturalists and physicians as well as the naturalists from abroad who visited Rome. The most prominent Roman fish expert was, of course, Ippolito Salviani (1514-1572), Papal physician, naturalist, professor of medicine at the Roman university, and author of one of the major works on fish and other aquatic creatures of this period, Aquatilium animalium historia (appeared between 1554 and 1558), which has 81 full-sized and beautifully executed copper engravings. ${ }^{43}$ Both Salviani and Horstius are

39 On Horstius and the hospital see Archivio di Stato Roma (ASR), Ospedale Santa Maria della Consolazione, Inventory 52-53: Entrate e uscite del Camerlengo 1204 (1549); and Registri dei Mandati 802 (1549). Münster 1960, 878-879 (with thanks to Giuseppe Olmi); Esposito Aliano 1980; Bosman-Jelgersma 1989, 17; and the references in Foreest's work mentioned in note 41 below.

40 Horstius 1544.

41 For references to Horstius by contemporary physicians, see Cronenburgius Dessennius 1555, 96r, 119v; Adam 1620, 217, 328; and especially Forestus (Foreest) 1610, Book I, 65, Observatio XXXIV, 58-59, as well as Forestus 1634, Book VIII, Observatio 3, 238-39; Book VIII, Observatio VI, 240, Book VIII, Observatio X, 242, Book VIII, Observatio XXI, 249.

42 The population was not much larger than c. 55,000 before the Sack of Rome in 1527, may have dropped as low as $11-15,000$ afterwards, and took a long time to recover. See Palmer 1990, 50.

43 Gudger 1934, 31. An earlier (but unillustrated) work on Roman fish which mentions the local names of 42 different fish is Giovio 1524. For Salviani, see Pinon 2002, 477-492. 
indeed known to have had a large network of friends and professional contacts in Rome and outside it: Salviani, for instance appears to have met Belon; Horstius may have done so too. ${ }^{44}$ Salviani seems to have dissected his fish on a regular basis, keeping the skin and some stuffed specimens as well as drawings of the animals. He writes that he communicated news about interesting new naturalia to his contacts "not only that I may not deprive them of the gratification which I myself enjoy, but also that from our mutual conversations on these new and strange objects, we may be able more satisfactorily to arrive at correct conclusions". ${ }^{45}$

The drawings on which Salviani's engravings were based and the drawings collected by Horstius must have originated more or less within the same ten to fifteen years or so in Rome (c. 1540-1550/54). Yet, evidence of contact between Salviani and Horstius does not emerge from a visual comparison of the 37 images sent by Horstius to Gessner and the further fish images in the Amsterdam albums, on the one hand, and the copper engravings printed by Salviani, on the other hand. They show many common themes, similar choices of fish, and occasionally even great similarity in the poses in which the fish are depicted, but the differences are in most cases too striking to suppose that they could have been based on a common source. The model drawings for Salviani's engravings and the drawings collected by Horstius therefore seem to have been made by different draughtsmen. There is, however, textual evidence of a close bond between these two fish experts in Rome. Salviani speaks highly of Horstius in the very first of the fish descriptions in his Aquatilium (figs 7a, 7b, 7c), which concerns the conger eel or sea serpent,

which was caught not far from the ancient city of Antio, which is now called Neptunno; ${ }^{46}$ and was taken as a very rare fish by fishermen to Rome to Gylbertus Horstius the famous physician of Amsterdam who is very learned in the study of the simples of nature; as he was on intimate terms with me, he offered it to me of his own accord to sincerely help me in my activities as much as he could, so that I should arrange for it to be engraved in copper. Because this seemed to be a rarer specimen and the others are more similar to congers in shape and colour of the body, it is easier to recognize them because of this. But this one I had engraved in copper and published because it is to be of more use to scholars than the common ones. ${ }^{47}$

44 According to the entry by M. Wong in Gillispie ed. 1970-80, vol. 1, 596, Belon met Salviani and Rondelet in Rome. Kentmann certainly knew Belon (probably from Wittenberg - both were there around 1542/43). The biographical information in the 2001 edition of Belon's Cronique mentions neither Salviani or Horstius nor details about Belon's visit to Rome, although he certainly must have passed through.

45 Bushnan 1840, with a memoir of Ippolito Salviani (here p. 24). Cf. Pinon 2002.

46 Modern Anzio and Nettuno.

47 Salviani 1554-58, 58: "Quem captum haud procul ab Antio veteri oppido, sive quod nunc vocant Neptunno, atque ceu piscem rarissimum Romam ad Gylbertum Horstium Amsterodamum medicum celeberrimum, ac simplicium naturae pervestigandae studiosissimum à piscatoribus delatum; ipse ut qui me perfamiliariter uteretur, meosque hosce conatus candide quantum posset iuvaret, mihi ut aere excipiendum curarem, ultro obtulit. Ego vero 


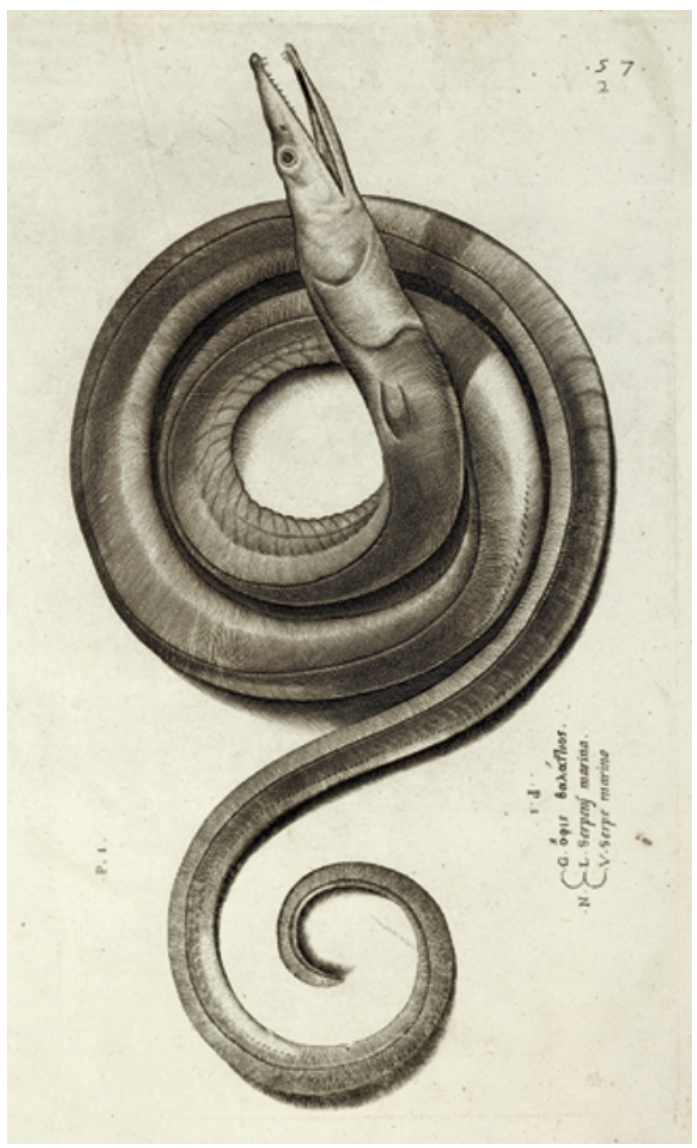

Fig. 7a: Salviani's sea serpent /conger eel. Salviani, Aquatilium animalium historiae liber primus (1554), plate 57. (Reproduced by kind permission of the Syndics of Cambridge University Library, shelfmark M.13.5.)

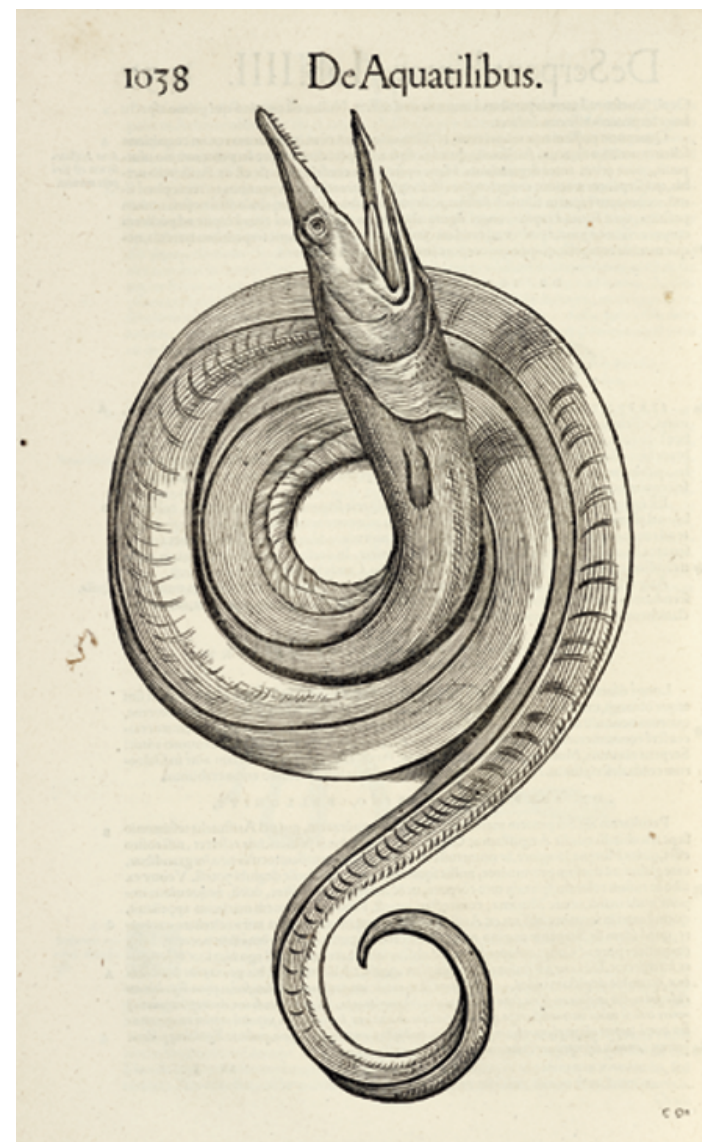

Fig. 7b: Gessner's sea serpent/conger eel. Gessner, Historia Animalium IV (1558), 1038. There is no corresponding Horstius or Amsterdam drawing for this. (Reproduced by kind permission of the Syndics of Cambridge University Library, shelfmark M.13.9.)

The two images of the "sea serpent" printed by Salviani and by Gessner are not reversed and very similar indeed, apart from some minor details that can be explained by the fact that a Swiss woodcutter and a Roman engraver were involved. ${ }^{48}$ Could they be based on two copies of the same drawing shared by Salviani and Horstius, of which one was sent by Horstius via Sittardus to Gessner? This seems probable, since Gessner says that he received the original drawing of the sea serpent "once upon a time from a friend in

quod rarior hic videtur, \& reliqui, utpote corporis forma \& colore Congris similiores, ex hoc facile cognisci possent; hunc potius in studiosorum utilitatem quam illorum frequentiorum aliquem in aes incidendum, evulgandumque duxi." There is no corresponding figure of the conger eel from Horstius.

48 Salviani 1554-58, 57; and Gessner 1558, 1038. 


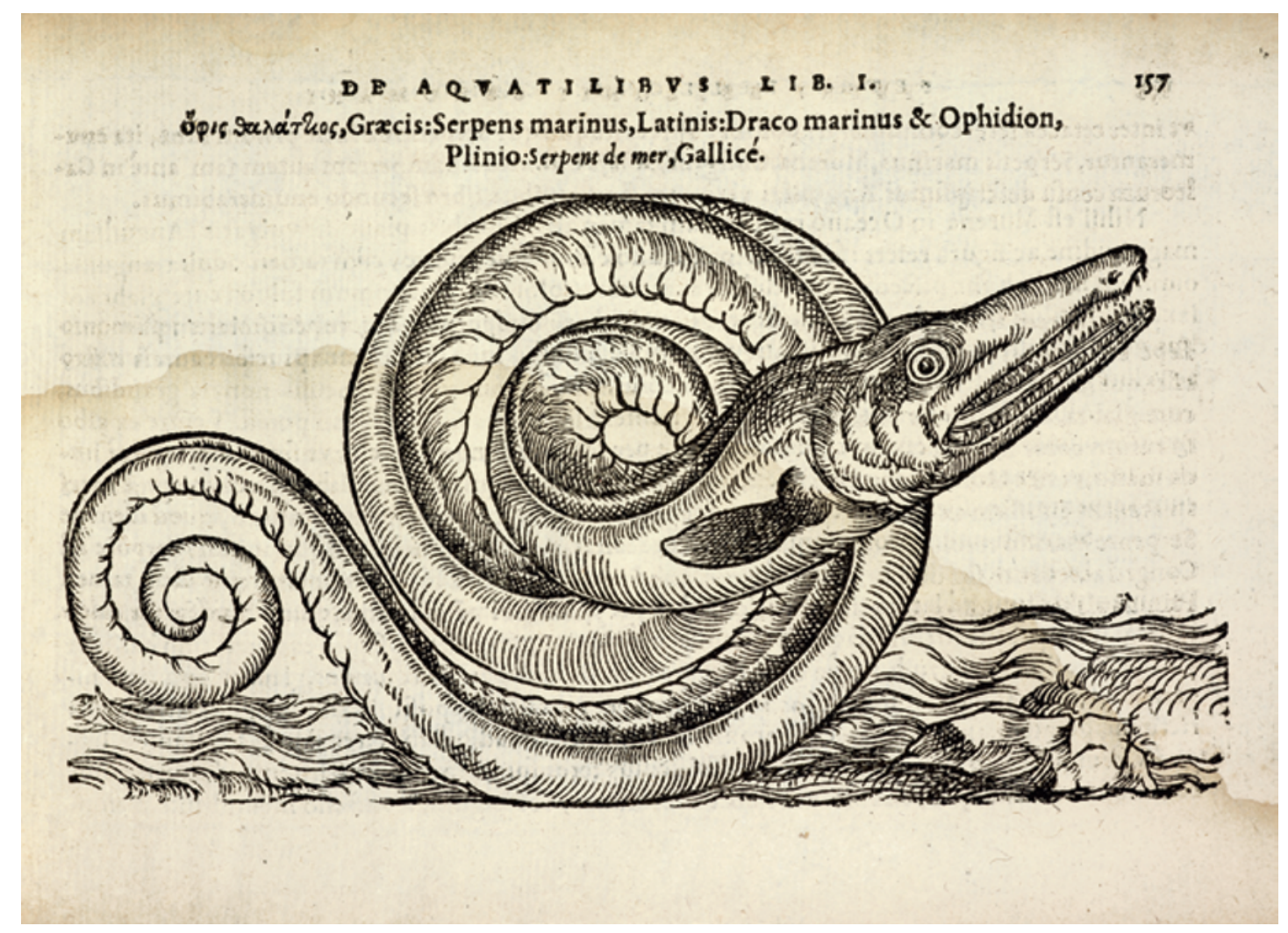

Fig. 7c: Serpens Marinus. Belon, De aquatilibus (1553), 157. (Reproduced by kind permission of the Syndics of Cambridge University Library, shelfmark $\mathrm{P}^{*} .6 .13(\mathrm{~F})$.)

Italy". ${ }^{49}$ That original drawing does not figure in the Amsterdam albums, but we presume it once formed part of the Horstius-Sittardus group.

Salviani's statement furthermore helps us to visualize the situation in Rome. Horstius and Salviani were on very friendly terms. They must have spoken regularly. Horstius knew of Salviani's project and of the production of the copper engravings. He may have visited Salviani's house, where the printing is supposed to have taken place, and he may have known the engravings or the persons making them for Salviani. Since Horstius presumably died in 1556 and Salviani's work began to appear in 1554, he probably even saw the first copies of Salviani's work. Horstius helped Salviani with information - in this case in the form of a fish, in other cases perhaps with images. The handing over of the rare fish from Anzio indicates too that both men must have valued first hand evidence. It is tempting to imagine them visiting the Roman fish market together, which was located at the Theatre of Marcellus, at only a few hundred meters distance from Horstius' hospital. The last phrase in the quotation above throws some light as well on the much

49 Gessner 1558, 1037: "ab amico ex Italia missam serpentis marini imaginem olim accepi". 
debated issue of the epistemic value of the rare or the exceptional to early modern naturalists. Salviani states that he includes an image in his book of Horstius' rare sea serpent or conger eel rather than of a more common one, because the more common ones were easy to recognize; an unusual one would therefore be of more help to naturalists - of help, presumably, in their attempt to identify the various species..$^{50}$

Salviani's brief reference to the fishermen of Anzio and Nettuno (some $60 \mathrm{~km}$ south of Rome) suggests that Horstius was known in Rome and the coastal towns of Central Italy as a fish expert and "curiosus" eager for news of unusual fish. How otherwise would these fishermen have known how or where to contact him and bring him the fish? That fits in well with what Rondelet from Montpellier writes about Horstius, whom he met in person when visiting Rome. Horstius had told Rondelet, as the latter writes, about a monstrous "sea lion" that was caught off the coast of Civitavecchia just before the death of Pope Paul III, who died in 1549. ${ }^{51}$ This tallies with the fact that Rondelet said that he was in Rome when Julius III had just become Pope..$^{52}$ While Rondelet was generally sceptical about the existence of various monstrous fish, ${ }^{53}$ their inclusion suggests that Rondelet valued Horstius's authority, and it also means that Gessner had another source for Horstius' images.

Sittardus was yet another visitor to Rome, who arrived with the abovementioned group of northern physicians including the ill-fated Valerius Cordus in September 1544. He seems to have stayed in Rome only briefly, to have left for Naples, and to have returned to Germany still within the same year 1544, where he acted as town physician of Nuremberg from $1546 . \mathrm{He}$ died there probably in 1550 or $1551 .{ }^{54}$ Horstius, on the other hand, was a permanent resident of Rome, an expert on natural history with the right contacts, and a collector of naturalia and images himself. It seems therefore probable that Horstius was indeed the source of the whole group of 37 (or 38

50 E.g. Céard 1977; Lestringant 1984; Daston/Park 1998.

51 Rondelet 1554/5, vol. 1, 491. The port of Civitavecchia (mentioned by its Roman name Centumcellae) is some $75 \mathrm{~km}$ north of Rome. Cf. Polish sea bishop Idem, p. 494; this image was received by Horstius from Amsterdam.

52 Rondelet 1554/5, vol. 1, 299. Entry by A. G. Keller in Gillispie ed. 1970-80, vol. 11, 527.

53 Lewis 2012, 11.

54 Sittardus's death is mentioned as a recent event in a letter dated 29 November 1550(?) from Joachim Camerarius the Elder to Hieronymus Herold the Elder, but some of Sittardus' own letters (to Melanchton) may be dated to 1551. See the online database Frühneuzeitliche Ärztebriefe des deutschsprachigen Raums (1500-1700) at http://www.medizingeschichte. uni-wuerzburg.de/akademie/index.html. The dating of Sittardus' return to Germany is tentative, and based on the remark by the English naturalist William Turner that Sittardus was with him at the dissection of a pelican while his (Turner's) book was being printed in Cologne: Turner 1544, G3r. 


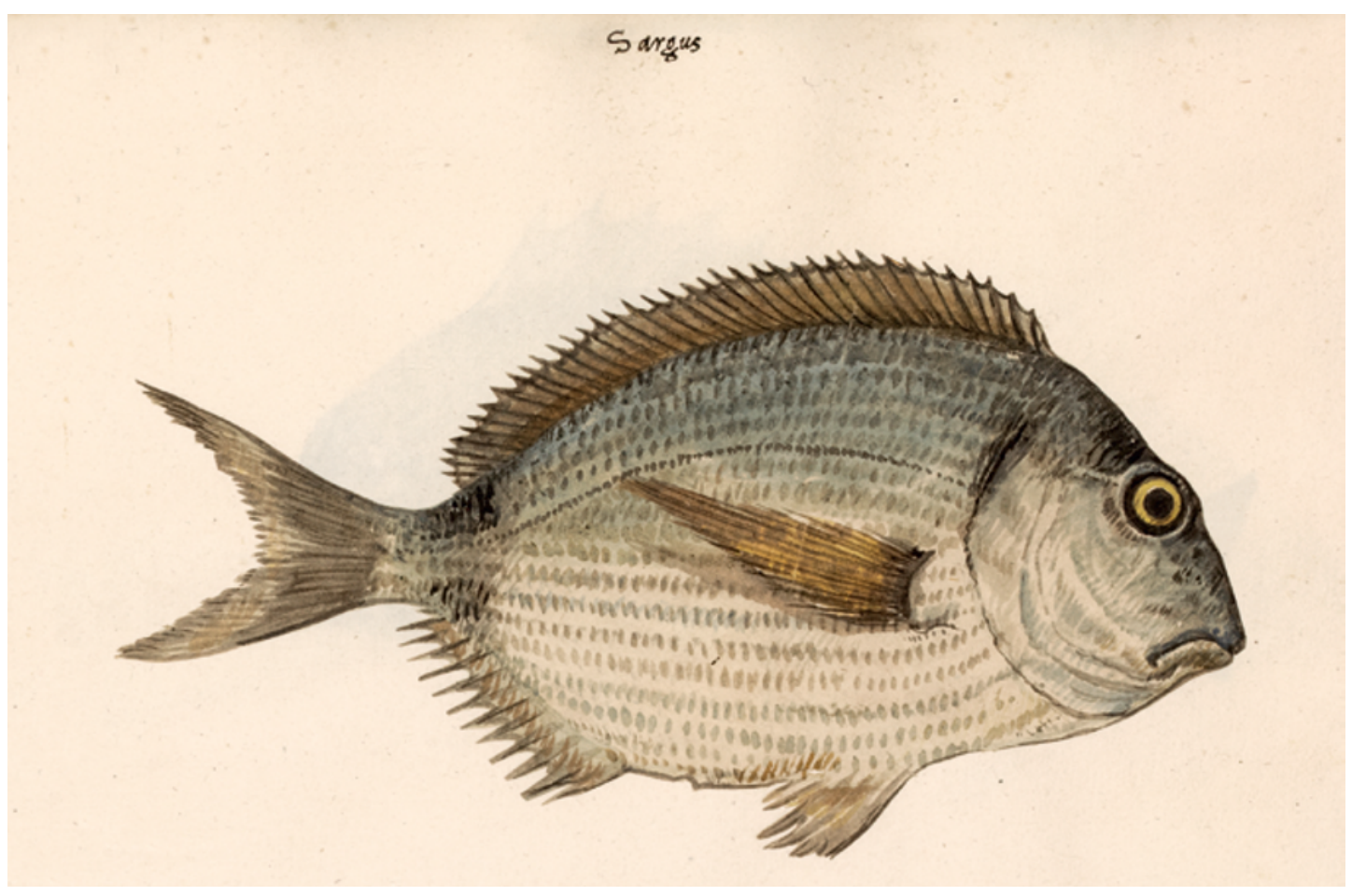

Fig. 8a: Sargus. Ms III C 22, 68. (Amsterdam University Library)

if we count the lost sea serpent) images that eventually reached Gessner. Since we also know that the images reached Gessner via Sittardus, and that Gessner (when writing his fish book published in 1558) speaks of some of them as received years or a long time ago, we may assume that these Roman images date from no later than c. 1544.

But complications of various kinds arise. The first is stylistic, and of particular relevance to the question of whether the group of 37 Horstius images that reached Gessner via Sittardus had more in common than the fact that they formed part of Horstius's collection. Could they have been made by one painter? An attribution to a single hand would help to support the assumption that Horstius commissioned these drawings from a particular painter and perhaps even for the specific purpose of sending them on to Gessner. Comparison of the images in this group leaves no doubt, however, that several painters with very different styles were involved in the making of these images. The sargus (III C 22, 68) (fig. 8a) and the torpedo (III C, 22, 122) (fig. 8b) could still be by the same hand given their brownish and grey colours, the rather crude brushwork, and the dashes. The mullus barbatus (III C 22, 88) (fig. 8c) is in a very different style with its bright colours and accents in gold and silver paint that highlight the eye and the fins, while the dolphin (III C 22, 102) (fig. 8d) is different yet again, with a very smooth-looking skin on which high- 


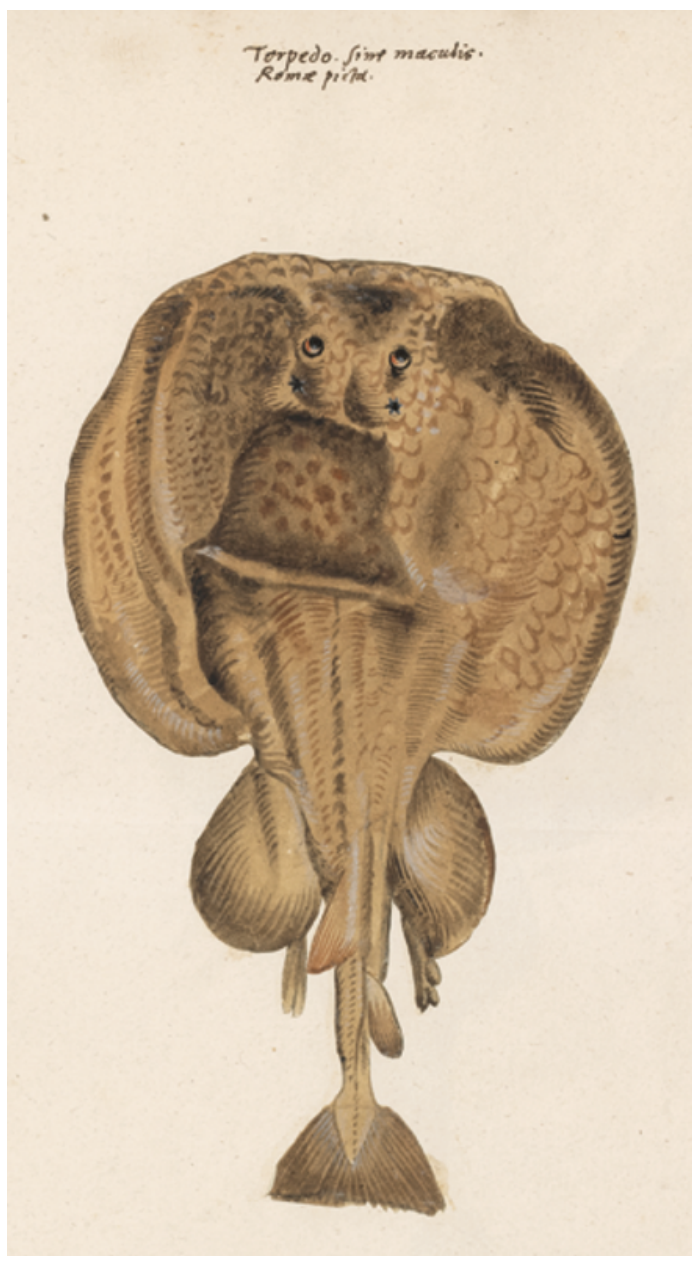

Fig. 8b: Torpedo without spots. Ms III C 22, 122 .

(Amsterdam University Library) lights in white have been used to suggest the shine on its round belly. Even if the annotation tells us that several of the drawings were made in Rome or had been sent from Rome, they were clearly made by different painters, even perhaps at different times. Others may have been given or sent to Horstius by his friends and thus may have come from other parts of Italy or even from abroad. The differences in style thus suggest that these images may have been collected by Horstius over a longer period and may have had very diverse origins - indeed, much like Gessner's own collection of images.

Two further complications concern the issue of copying and the circulation of more than one "original" copy. There is evidence that Gessner and his publisher had more than one drawing to work from, at least in some cases, when creating the woodblocks for the printed illustrations. In his section about the monstrous-looking galeus centrinus

Gessner writes: "this is the image of a Galeus centrinus, made in the past by one of our woodcutters after a picture that was made after an original (archetypum) sent [me] by Cornelius Sittardus as the image of a Vulpe marino". ${ }^{55}$ It was common practice for an author or publisher to copy an original image and use this copy as the model drawing, which was often destroyed in the

55 "Imago haec Galei centrinae est, a nostro quodam sculptore olim facta ad picturam cuius archetypum Cornelius Sittardus pro Vulpe mar. miserat," Gessner 1558, 1250. Sculptor refers to the man cutting the woodblock. Vulpe marino means sea fox; the long-tailed or common thresher shark, Alopias vulpinus, is also named the fox shark (Greek alopex means fox). The German edition of Gessner's fish book, which still appeared during Gessner's lifetime (1563), presents exactly the same image, but with a different caption, which states that this fish had been precisely depicted in Venice (p. LXXIX). It is unclear whether this is an error or additional information suggesting that Sittardus passed through Venice and collected images there as well as in Rome. 


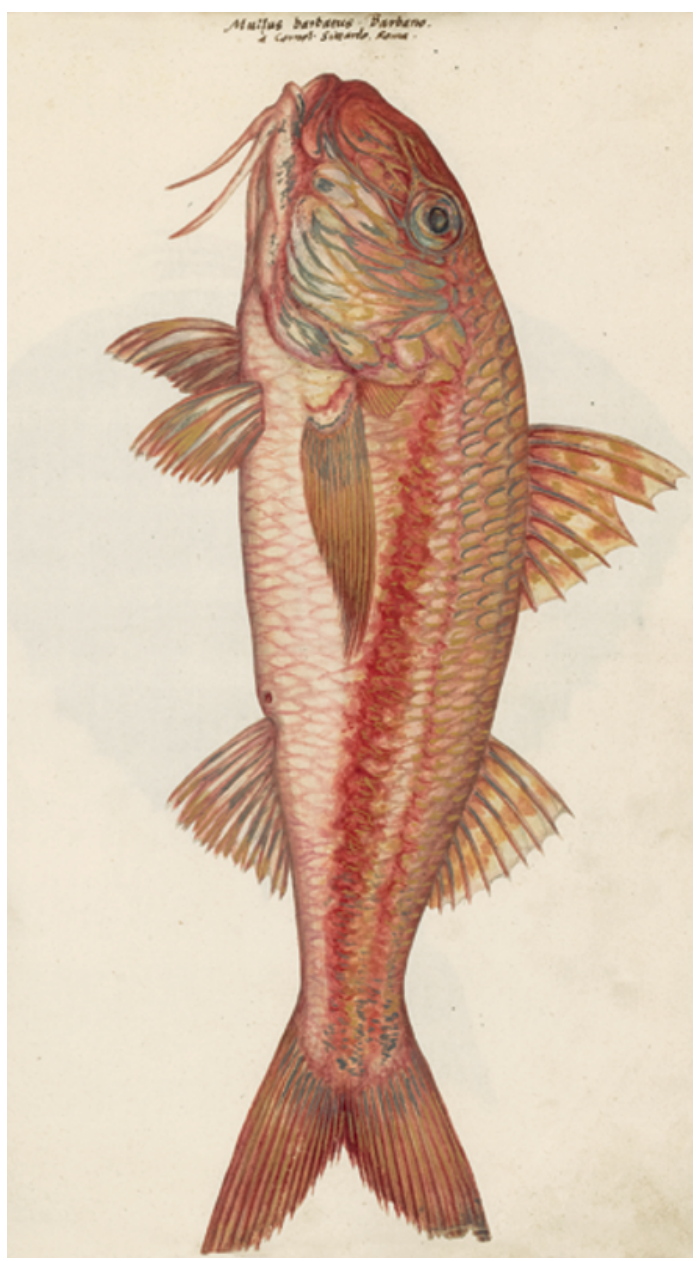

Fig. 8c: Mullus barbatus.

Ms III C 22, 88 .

(Amsterdam University Library)

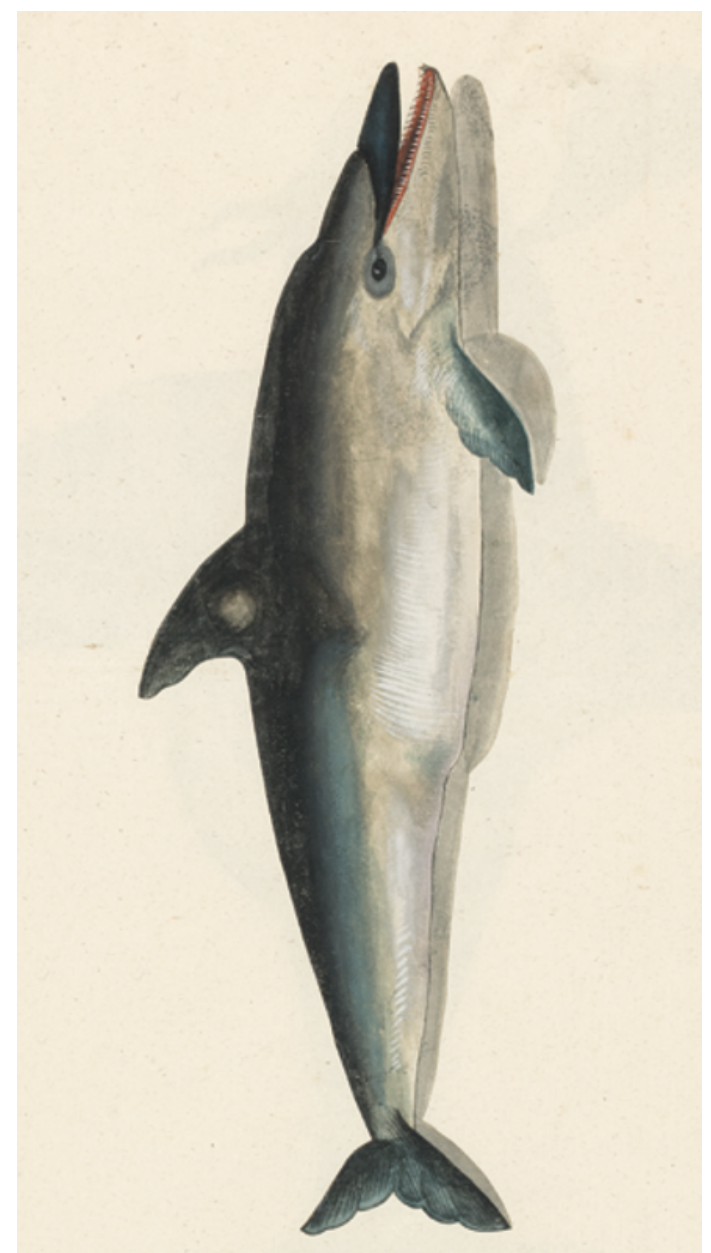

Fig. 8d: Dolphin.

Ms III C 22, 102.

(Amsterdam University Library)

process of being transferred to a woodblock. Such a copying practice would explain various kinds of minor differences that we find between the originals in the Amsterdam drawings and the printed illustrations.

Finally, the two Holthuis watercolours at Leiden do not fill a "gap" in the Amsterdam albums, but are twin images of those contained in the albums, except that the Amsterdam albums do not show the animals together in a composition since they have been cut out (figs 9a, 9b). ${ }^{56}$ The colours of the fish in the Amsterdam album are fresh and stronger than in Holthuis' drawings, but very similar in kind. The creatures face the same way as the Holthuis animals, although Platter pasted the right-hand figure of the tethya up-

56 Only in one case (acus) a narrow line of shading can be seen, which must have escaped the scissors. 


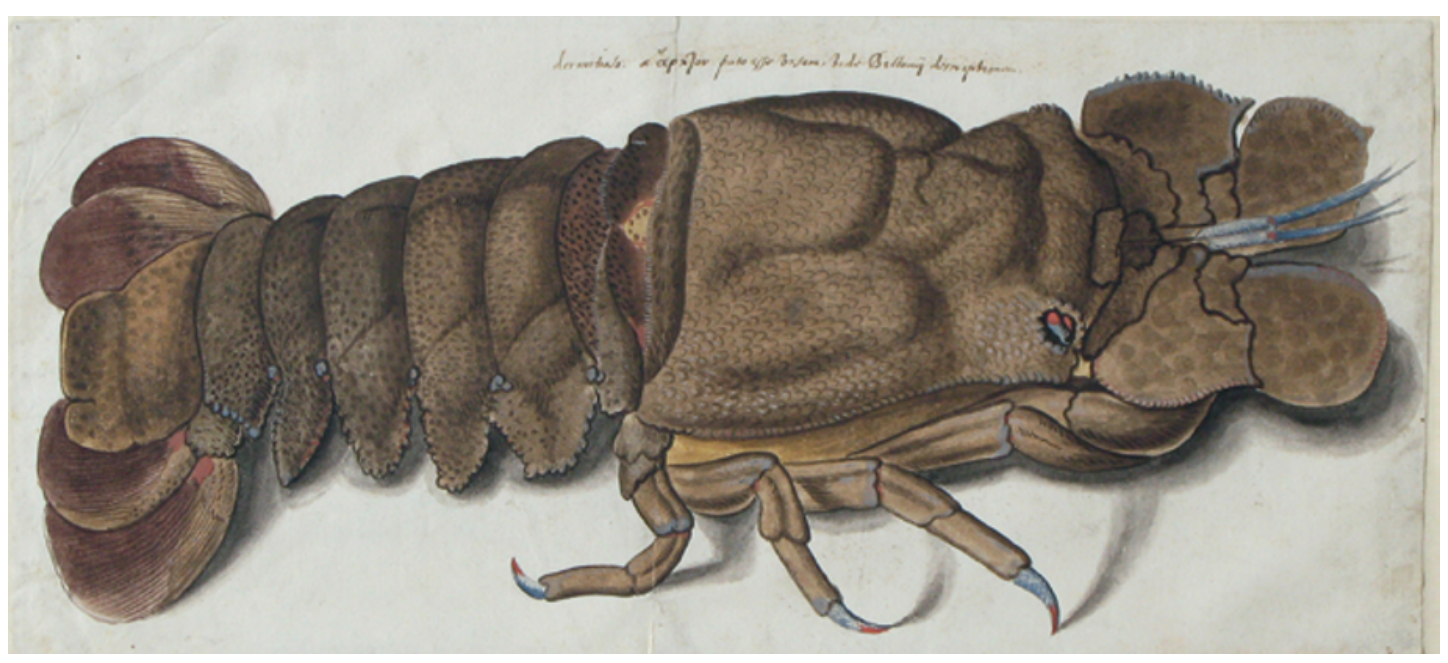

Figs 9a: Holthuis' squillus latus. (Naturalis, Biodiversity Center, Leiden)

side down. For each of these particular species, therefore, we now appear to have two "original" drawings which match each other almost perfectly, while both mirror the reverse-printed images in Gessner. If two originals are possible, why not three or more?

\section{Kentmann and Röting matches}

Johannes Kentmann (1518-1577) had, after studying at Leipzig, Wittenberg and Nuremberg, travelled to Italy with his friends to study medicine (154749). While studying at Padua and Bologna, he also visited Florence, Naples, Rome, and elsewhere in Italy. His itinerary was therefore almost virtually the same as that followed only four or five years earlier by the group of young northern physicians including Foreest, Cordus, and Sittardus. Kentmann obtained his MD at Bologna in 1549, returned to practice in Meissen, and then became town physician at Torgau. ${ }^{57}$ His study of human kidney-stones was published in 1565 (Calculorum qui in corpore ac membris hominum innascuntur genera XII) in a collection that included Gessner's work on fossils. Kentmann had compiled a pictorial record while he was in Italy, an "Observationes" based on first-hand examination of plants which included one of the earliest depictions of the tulip in Europe as well as of plants grown in the newly established medical garden at Padua. ${ }^{58}$ Kent-

57 Helm 1971.

58 Ms Codex Kentmanus, Anna Amalia Bibliothek, Weimar. Kusukawa 2009. For the concept of observation in this period, see Pomata 2011. 


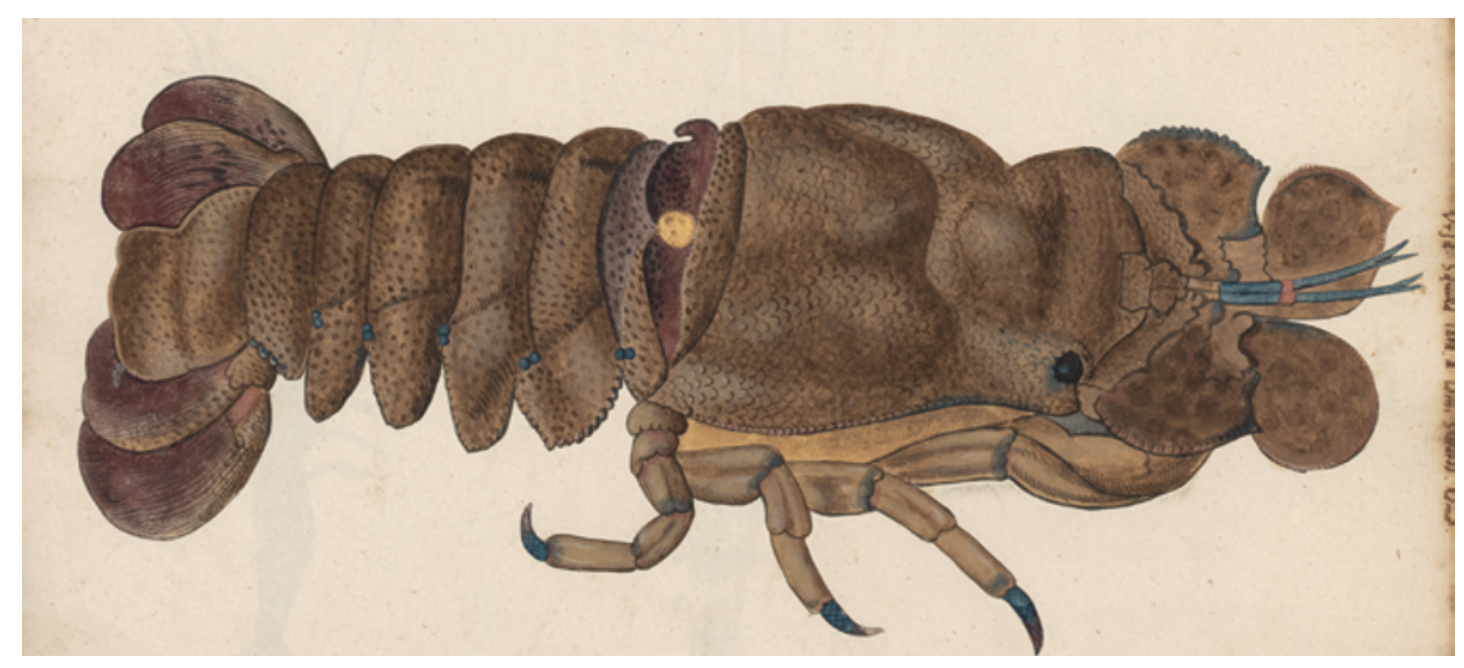

Fig. 9b: Squillus latus. Ms III C 22, 204. (Amsterdam University Library)

mann's album, now comprising "Codex Kentmanus" at the Anna Amalia Bibliothek in Weimar, also included a set of images of water animals and amphibian creatures. ${ }^{59}$

Shortly after returning from Italy, in 1550, Kentmann sent Gessner a list of names of animals whose pictures Kentmann offered to show him. Gessner replied to say that he already had figures of several of them from Sittardus and others, but he still asked for images of "S. Peter", "Pompiles" and "Claves". ${ }^{60}$ Gessner said that if Kentmann sent the images to him, he promised to return them to him, or, if Kentmann would have figures copied from his originals (exemplaria), he would ensure that the printer, Christoph Froschauer, would reimburse him at the next Frankfurt fair. ${ }^{61}$ Kentmann eventually sent his drawings of plants and aquatic animals to Gessner. Gessner returned them by 16 March 1555, when he also mentioned that Rondelet had recently published in Lyon a two-volume work on fishes. ${ }^{62}$ We know that Gessner had studied Kentmann's drawings of plants as he left annotations on some of them, though no annotations by Gessner are found in the fish sec-

59 The section on aquatic animals is entitled 'Animalium Aquatilium in mari et dulcibus aquis degentium, ICONES ad vivum expressae, a Ioanne Kentmanno medico, 1549', Codex Kentmanus, $146 r$.

60 Gessner 1584, 22 April 1550, A1r.

61 "Quod si picturas tuas miseris, eandem bona fide remittam: sin ad exemplaria tua depictas, curabo ut impensas numeret typographus nostras in nundinis animalibus Francofordiis."; Gessner 1584, 22 April 1550, A1r.

62 "Remitto tibi, optime Kentmanno, librum tuum pulcherrimum, quo stirpium et animalium icones permultas et raras dilgenter complexus es: ac pro hoc benefice gratias tibi immortals habeo." Gessner 1584, 16 March 1555, A3v. 


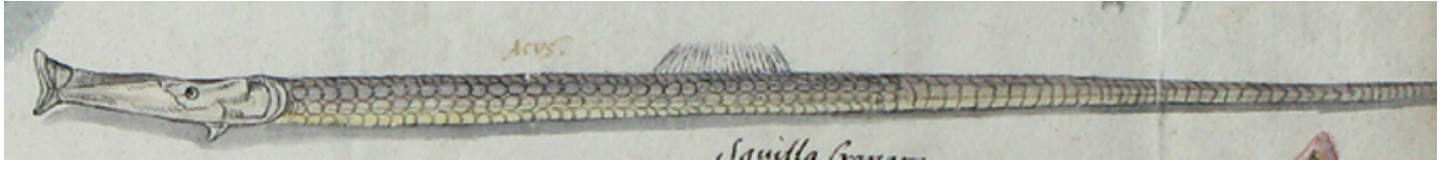

Fig. 10a: Acus, detail from Holthuis's watercolour. (Naturalis, Biodiversity Center, Leiden)

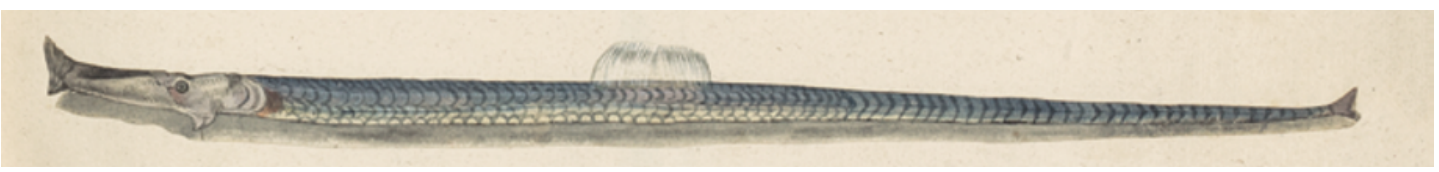

Fig. 10b: Acus. Ms III C 22, 107. (Amsterdam University Library)

tion. ${ }^{63}$ Several of these fish drawings in Kentmann's album were remarkably similar (though inverted) to those woodcuts in Gessner's volume of fishes that were given a Sittardus provenance. In 2010, it was conjectured that Gessner must have received a set of drawings from Sittardus that were very similar to Kentmann's, and that the common source for these drawings was most likely to be Horstius. ${ }^{64}$ Kentmann was in Rome between February and April $1549,{ }^{65}$ and had visited Gysbert Horstius's garden in Rome as he cites the plants he had seen there. ${ }^{66}$ Furthermore, the close match between the Holthuis drawings now at the Naturalis library and those of Kentmann pointed to multiple copies of drawings originating from Horstius. ${ }^{67}$ The discovery of the Amsterdam Albums indeed confirms that Gessner had drawings sent by Sittardus that closely matched those of Kentmann and further suggests that there were several more drawings originating from Horstius.

Of the 142 images of chiefly aquatic creatures in Kentmann's albums, over fifty overlap with those in the Amsterdam Album. Of these overlapping images, fifteen are attributed (by Platter) to Kentmann explicitly in the Amsterdam albums, thirteen to Sittardus, and twenty-five to none. Of the last category, a further eleven can be attributed to Sittardus from the text that accompanies the printed version, and one more to Kentmann (figs. 11a-d). On the other hand, there are seven drawings in the Amsterdam album with a Kentmann provenance that do not have a corresponding image in the Codex Kentmanus. We might speculate that these are drawings lent by Kentmann to Gessner but never returned by the latter, but here we would like to

63 Gessner's annotations are found in Codex Kentmanus, 69v, 81r, 84r, 86v, 87v, 90v, 91r, 93r, $96 \mathrm{v}, 104 \mathrm{r}$, and $109 \mathrm{r}$.

64 Kusukawa 2010, 312-322.

65 Helm 1971, 20.

66 Kusukawa 2009, 452-453.

67 For the Leiden drawings, see Holthuis 1996. 


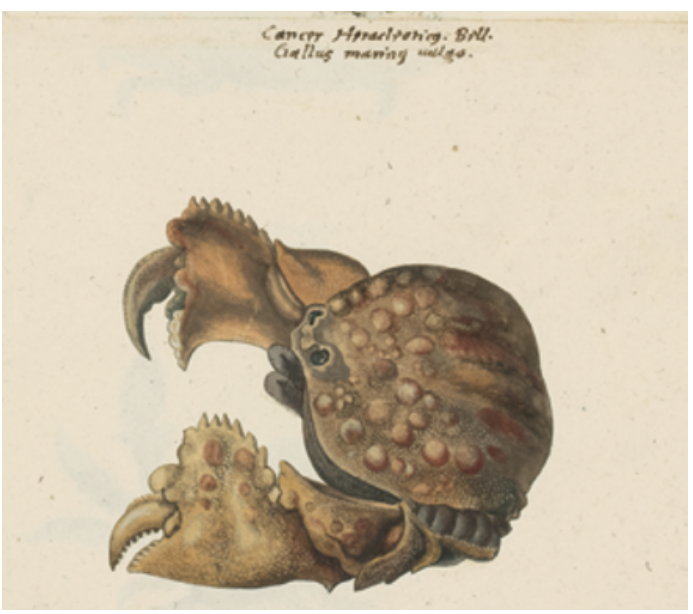

Fig. 11a: Cancer Heracletius Bellonij. Ms III C 22, 200.

(Amsterdam University Library)

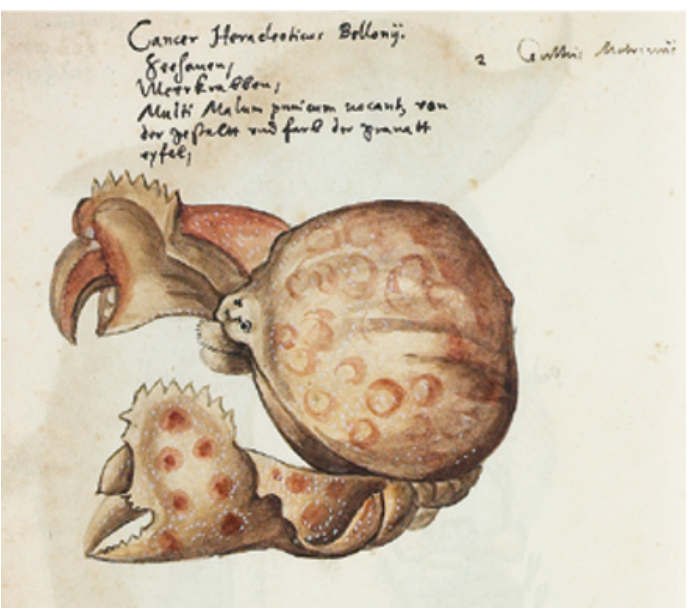

Fig. 11b: Cancer Heracletius Bellonij. Codex Kentmanus, 155v. (Herzogin Anna Amalia Bibliothek, Weimar)

confine our discussion to the drawings that both Kentmann and Sittardus had, which we believe originated with Horstius.

Before comparing the Kentmann and Sittardus drawings stylistically, we should briefly return to the Holthuis watercolours at Naturalis Biodiversity Center. As remarked above, nearly all of the species depicted in these have matches in the Sittardus-Amsterdam drawings. But for these same species the Kentmann albums too contain original drawings, which again are highly similar except in small details. In this unusual case, we are confronted by three sets of "original" early modern drawings. Whether the Holthuis-Naturalis drawings originated with Horstius too, or were copied after either the Kentmann or the Sittardus drawings or after yet another set of copies, must remain an open question for the moment.

The case of the "featola"(stromateus) is typical of the similarities and differences that can be observed between the Sittardus (fig. 6b) and Kentmann drawings (fig. 12). In both drawings, the outline of the dorsal fin is roughly continuous with the outline of the head, the tail fin is forked, the pectoral fin has a roundish root, next to which (to the right) is a triangular dark spot; the mouth opens in a similar way and the eye is in a similar position. The matches in outline and some details suggest that these two drawings must be closely related as drawings in the sense that they are copies of a common drawing, rather than drawings of the same or common object. Yet, the drawings are not identical in that the placements of the marks on the body do not match up precisely, though both show fewer marks on the dorsal side. The width relative to the length of the fish is different, and thus Kentmann's fish looks 


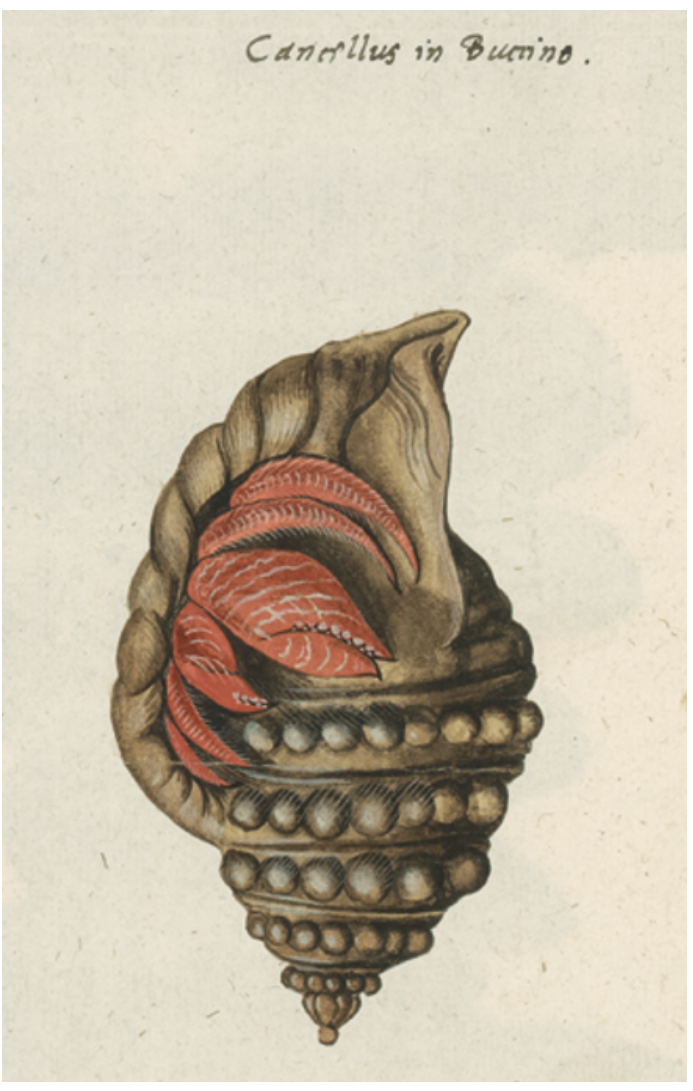

Fig. 11c: Cancellus in buccino. Ms III C 22, 203. (Amsterdam University Library)

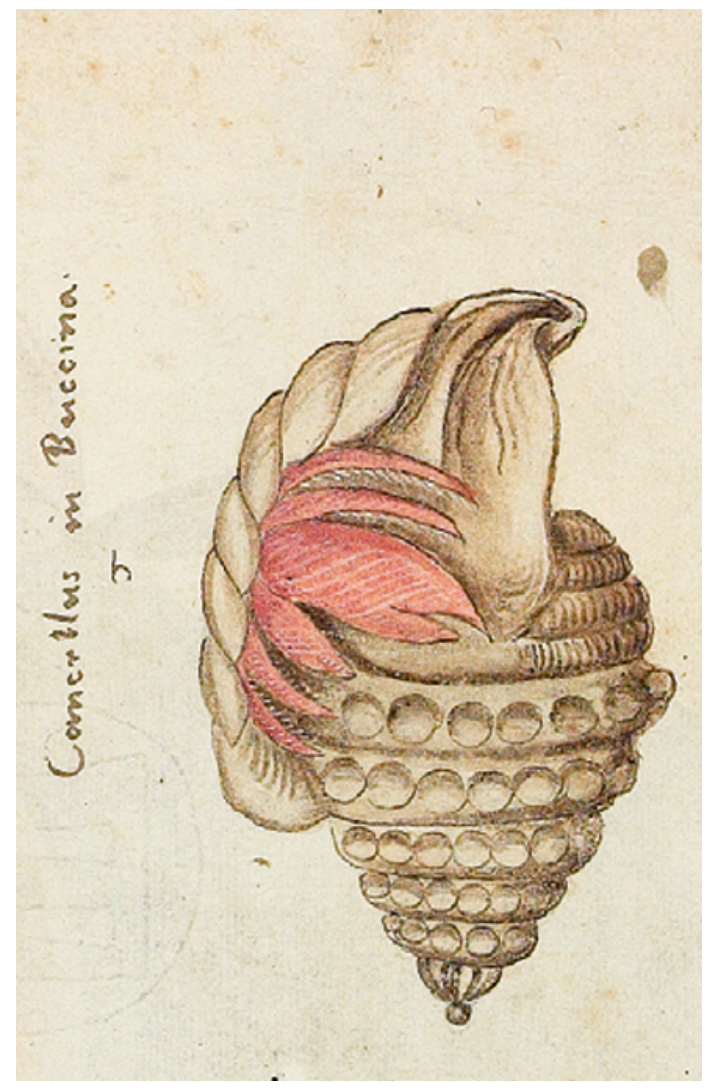

Fig. 11d: Cancellus in buccino. Codex Kentmanus, 156r (rotated anti-clockwise). (Herzogin Anna Amalia Bibliothek, Weimar)

plumper. This suggests that these are results of free-hand copying, rather than using some means of tracing directly from an original.

Above all, the colouring creates a very different impression. The dorsal and ventral fins are painted in both cases in a similar grey colour, but Sittardus' pectoral fin is coloured in dark grey while the colour of the corresponding fin in Kentmann's drawing is much lighter. Kentmann's featola is painted in alternate strips of light blue and pink, with thin white crosshatches along the dorsal half of the body, and darker cross hatches used to the left of the centre of the body and on the yellow marks on the ventral side. Vertical strands of pink and blue are also visible in Sittardus's fish, but an additional grey and ochre are used to provide a darker body colour and a three-dimensional modelling of the body. White cross-hatches are also used in Sittardus's drawings as highlights, and darker cross-hatches are visible on the ventral spots: the overall result here is the look of a silvery striped body with lozenge-like marks. The striking difference between the two drawings is in the finish of the head: where Sittardus's drawing shows a clearly con- 


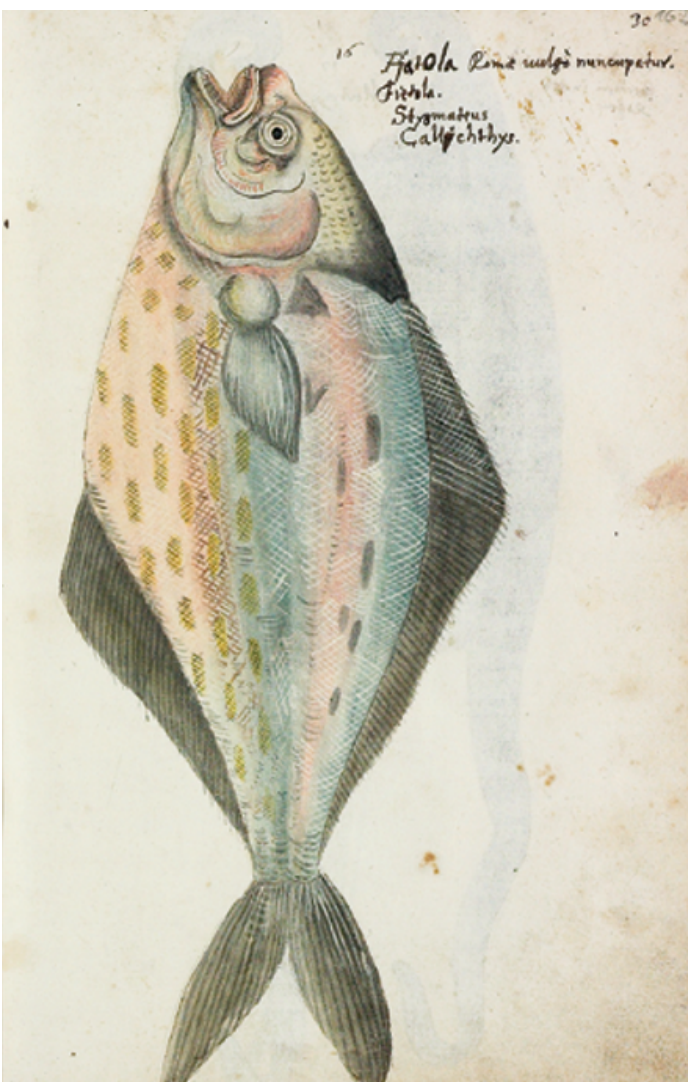

Fig. 12: Fiatola. Codex Kentmanus, 168r. (Herzogin Anna Amalia Bibliothek, Weimar) toured gill, using yellow, ochre and red, Kentmann's fish is coloured using the same light blue and pink colours as used on the body, and thus the head looks less well defined. It is almost tempting to conjecture that the craftsman who painted Sittardus's featola knew what the fish looked like, while the one who did Kentmann's drawing was only interested in superficial copying.

These are features that can be detected in other drawings shared by Sittardus and by Kentmann. While the matches in the outlines and details suggest very strongly that they are drawings copied from a common image, the figures of fish look very different because of the finish - typically, Sittardus's drawings show a wider range of colours and the colours are placed in such a way as to enhance the three-dimensionality of the fish; fewer and lighter colours are used in Kentmann's drawings and give a flatter impression - indeed Kentmann's fishes never cast any shadows, while several of Sittardus's do (when they have not been trimmed down to the outlines of the fish) as do the ones in the Naturalis drawings (figs 13a-c).

The techniques and skills deployed in the drawings of Kentmann and Sittardus are so different that it would be very difficult to claim that these were made by the same hand. While we know that Kentmann drew and painted some of the plants he saw in Italy, the techniques used in the fish drawings of the Codex Kentmanus seem to be quite different, and it is at present unclear whether Kentmann himself had done the drawings while at Rome. It is unlikely that these sets of drawings originated from the same "workshop", for example, even if they might have offered different qualities of colouring according to the price customers were prepared to pay. ${ }^{68}$ 


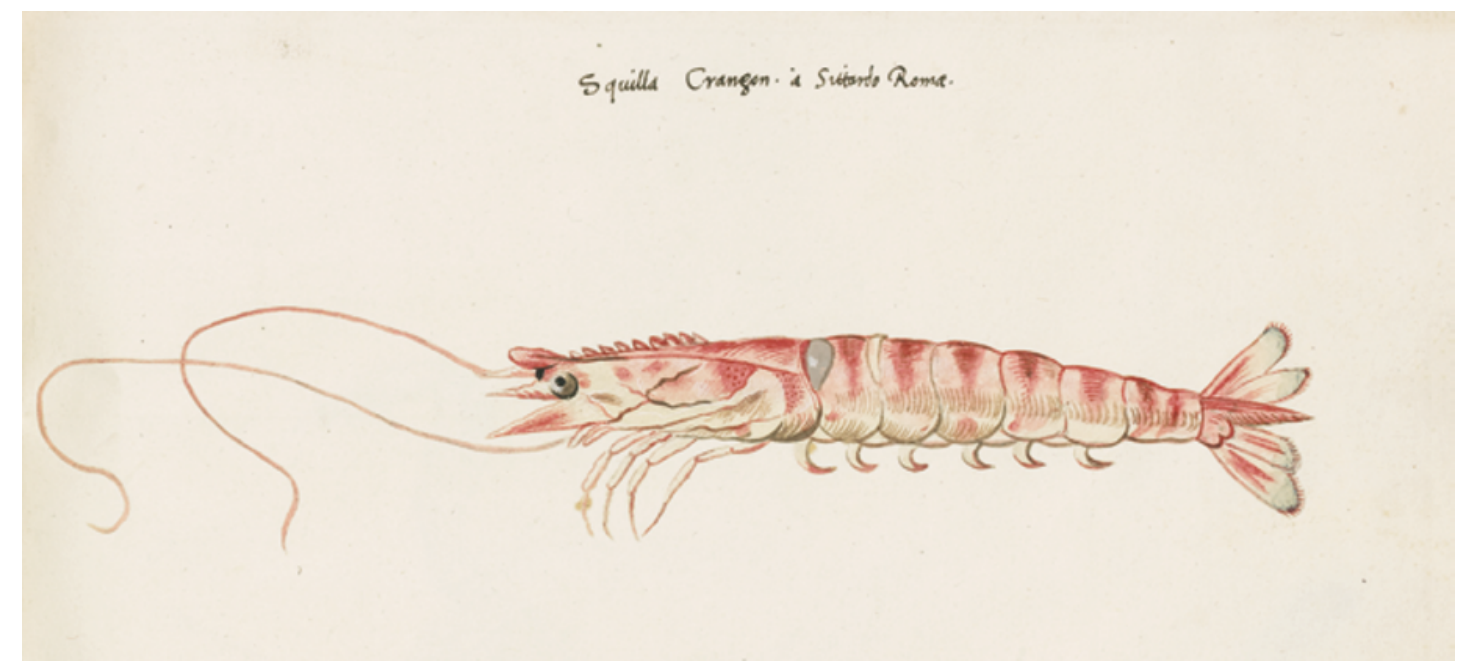

Fig. 13a: Squilla crangon. Ms III C 22, 205. (Amsterdam University Library)

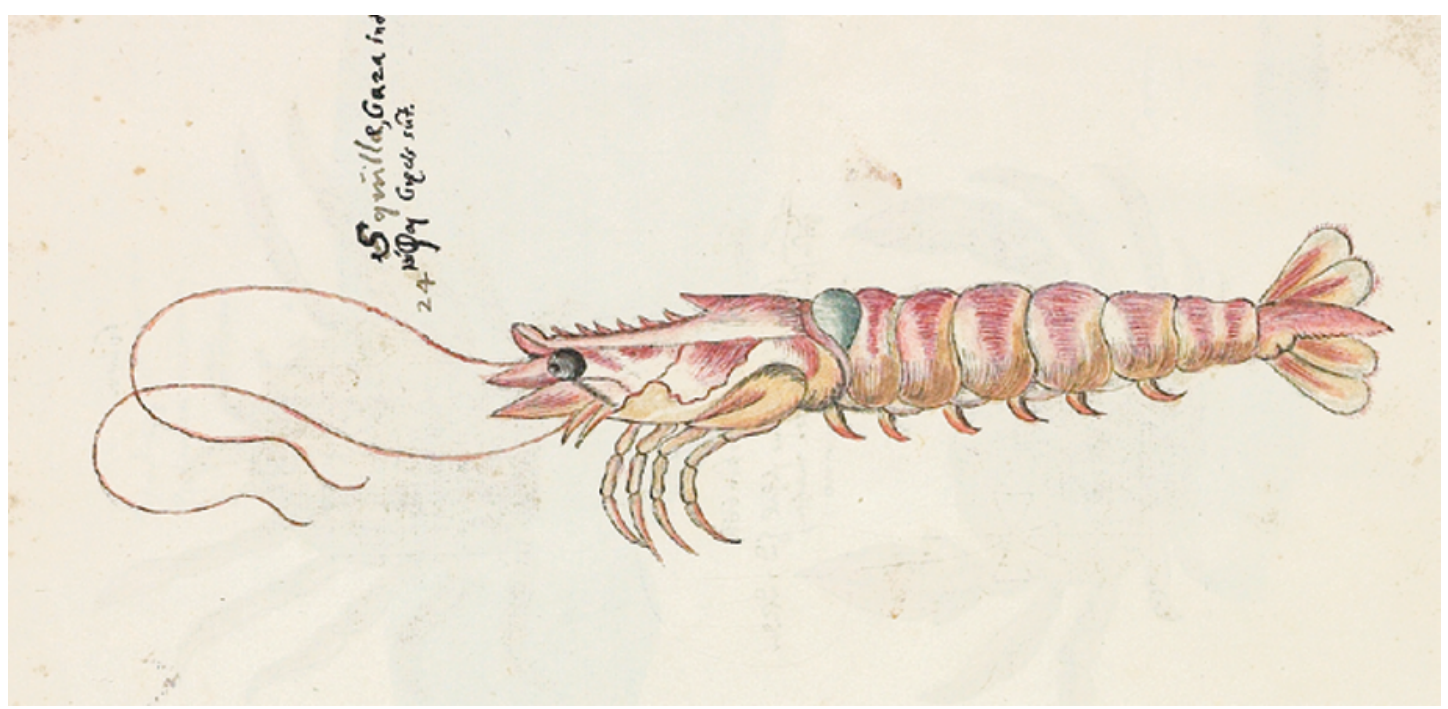

Fig. 13b: Squilla crangon. Codex Kentmanus, 166r. (Herzogin Anna Amalia Bibliothek, Weimar)

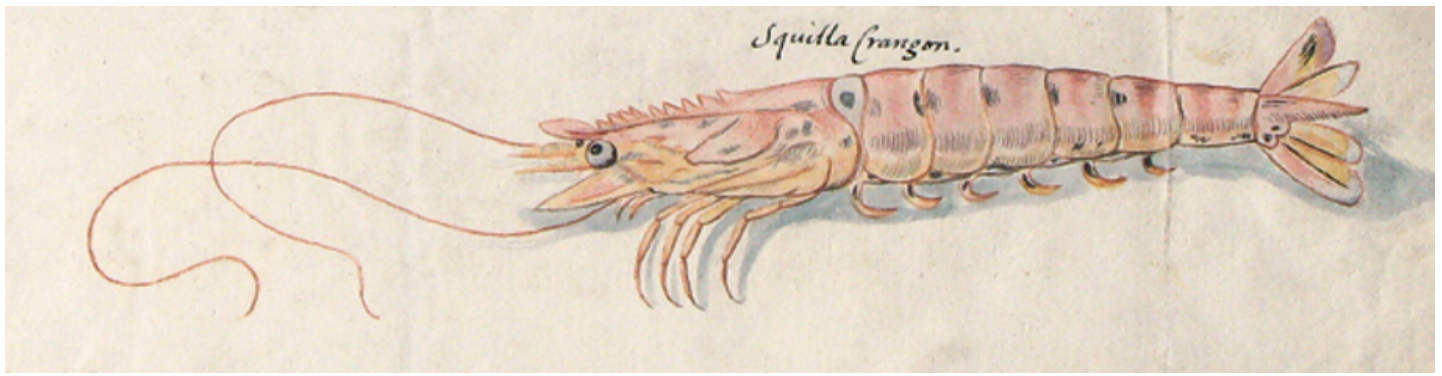

Fig. 13c: Squilla crangon, detail from Holthuis's watercolour. (Naturalis, Biodiversity Center, Leiden) 


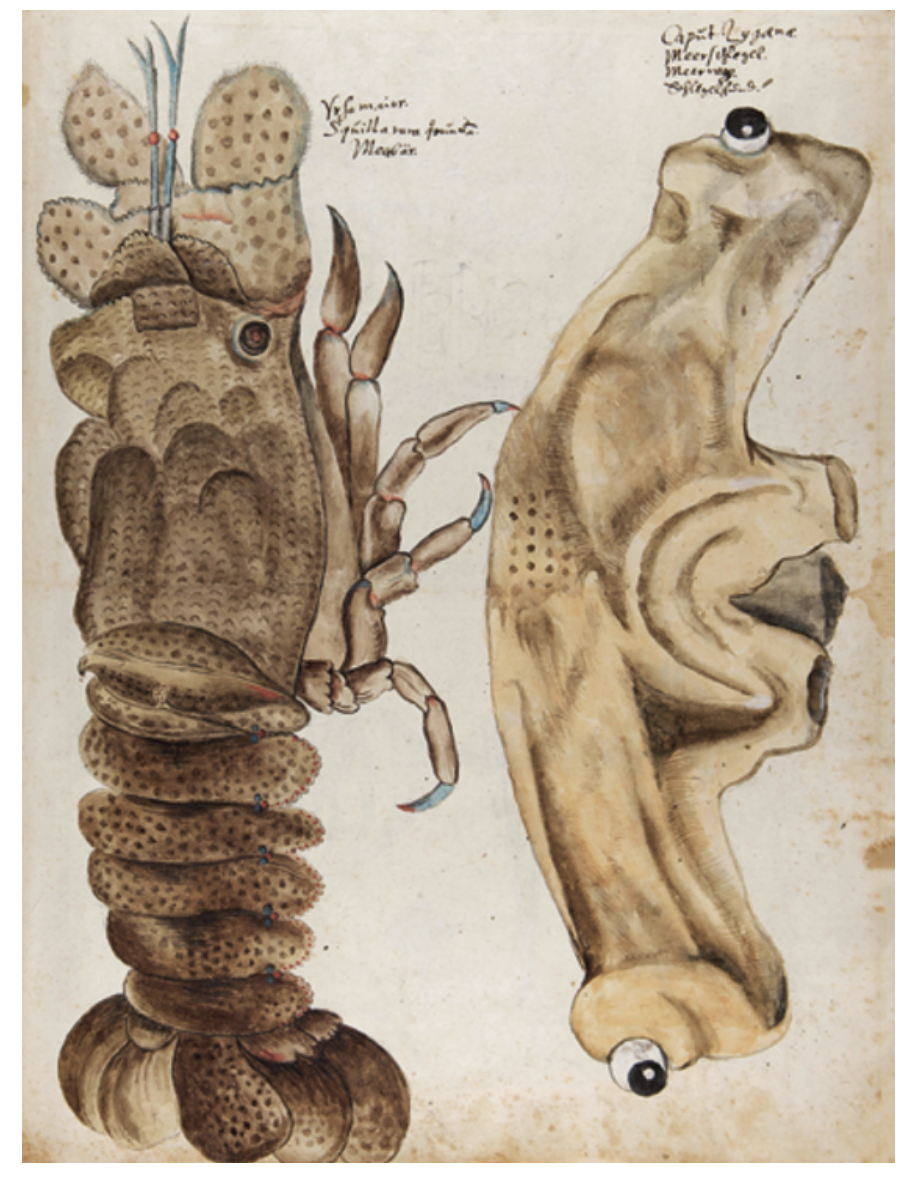

Fig. 14: Squillus in Lazarus Rötung's album, Theatrum Naturae von Michael Rötenbeck,f. 152. (Museum für Naturkunde, Berlin)

One more - and thus a fourth - original drawing came to light a few months before this article went to press. (fig. 14) It depicts the large lobster (squillus latus) of which we have already found drawings in the Amsterdam Album, the Naturalis drawings, and the Kentmann collection. This fourth lobster can be found in a late sixteenth-century South-German album with naturalia drawings that is largely devoted to birds. The naturalist and selftaught painter Lazarus Röting (1549-1614) spent much of his life painting birds, generally close to his home in the Nuremberg region since he was disabled. He furthermore copied animal drawings after famous as well as completely unknown artists, but also after woodcut illustrations and pamphlets. His nephew, Michael Rötenbeck, who had trained as a physician, worked closely together with Röting, inherited the latter's drawings, which appear to have been created mainly during the period c. 1580-1614, and had them bound in the album Theatrum Naturae (1615). Whether the drawing of the lobster in this album was made by Röting personally, or collected by him (or his nephew) needs further investigation. The fact that it faces right (just like the other three drawings, and in contrast to the printed illustration) and is accompanied on the folio by a copy after yet another of Gessner's fish im- 
ages - the skeletal head of a hammer fish - strongly suggest that the Röting drawing was not copied after printed illustrations, but after original images. Moreover, the small differences between the Kentmann, Amsterdam and Röting drawings in both painterly technique and the shape of body parts of the lobster (e.g. tail, eye, walking legs) suggest free-hand copying. The question must remain open whether the Röting drawing is based on one of the abovementioned three sets or on yet another model. It is suggestive, however, that Röting was from Nuremberg, the same town where Sittardus lived and practised as town physician a full generation earlier. Could local copies of the images that Sittardus had carried from Rome have been made and circulated in Nuremberg? Was Röting's father, director of the Nuremberg gymnasium, perhaps in touch with Sittardus? ${ }^{69}$

Obviously, further research and more evidence may lead to a new perspective on this material, but thus far the matches between the Kentmann drawings, the Röting drawing, two Holthuis watercolours in Naturalis and the aquatic drawings connected with Sittardus in the Amsterdam album point to the following direction. The Sittardus drawings in the Amsterdam album, the Kentmann ones, and the Röting drawing appear to be free-hand copies that go back to a common source: the Horstius collection of drawings in Rome. The thirty-seven Sittardus drawings in the Amsterdam albums certainly originated in Rome, most likely before the end of 1544. Given stylistic differences between the Sittardus and the Kentmann drawings it is unlikely that the Sittardus ones were the ultimate common source that belonged to Horstius. Indeed, there is a practical reason as well why this is unlikely: if Horstius gave away his own original drawings to Sittardus (for Gessner) in 1544 , he would not have had the same models left to be copied in 1549 by or for Kentmann. Stylistic differences within the group of thirty-seven Sittardus drawings in Amsterdam are considerable. They cannot have been made by one artist, nor probably by one atelier. We therefore assume that the painters who copied these images after Horstius' personal collection also copied the stylistic differences of Horstius' images. Another possibility is that Horstius had a large stock of doubles and triples, made at different times and by different artists, which he shared out to friends.

The Kentmann drawings likewise originated in Rome, and in 1549 were copied - most likely by a local painter, who used rather faded and limited colours - from the drawings in the possession of Horstius. Whether the two

69 Michael Rötenbeck, Theatrum Naturae (1615), 190 folios, Museum für Naturkunde, Berlin. The majority of the drawings are unpublished. See esp. Hackethal 2010. More research is also required concerning the presence of other Gessner- or Kentmann-linked animals in this album. 
Holthuis watercolours in Naturalis are yet further contemporary copies of the same originals is unclear, and only further research concerning provenance, pigments and paper used in these two drawings may be able to answer the question of how old they actually are and of whether they could be later copies. And until more information is available about the Röting collection, we assume that the Röting lobster was copied in the last quarter of the sixteenth century, probably in Germany. Horstius' original collection in Rome no longer exists, we imagine, but thanks to the copying, circulation and exchanges between naturalists at least the surviving copies give us some idea of what it contained.

For the moment we can only speculate about the origins of Horstius' own collection. Like Salviani, he must have collected images locally, made by Roman draughtsmen (perhaps even by himself), based on fish caught in the Mediterranean and seen, for instance in the fish market. But he certainly received images from abroad as well, and in all likelihood from other parts of Italy. He exchanged information and perhaps images with his fellow Roman fish expert Salviani, and he was involved in exchanges with other naturalists. Geographically, some of his images left Rome (as copies), travelled to Gessner in Zurich (perhaps first reaching Sittardus' home town Nuremberg), while another set of copies was carried by Kentmann from Rome to Meissen. Some of the images from Kentmann's set then travelled on to Gessner, who may have returned some and kept others. Perhaps, images from Gessner's set too were sent to Kentmann and returned by the latter. Since Horstius was in touch with Rondelet as well, it is possible that he sent more images to Rondelet than only the sea bishop and sea lion. And because so many of Rondelet's printed images were re-used by Gessner, Horstius' images may have been an even more important source for Gessner than we can tell on the basis of the originals that we have at our disposal at present.

\section{Principles of selection}

Not all of the Sittardus-Kentmann-Horstius images were printed by Gessner. It is difficult, however, to establish consistent or clear principles of selection on the part of Gessner. He often showed critical judgement - as in the case of the swordfish whose figure was created by using the top of one and the bottom half of another image, or in the case of a herring, which was an amalgam of woodcuts from Rondelet and Belon. ${ }^{70} \mathrm{He}$ could call a figure "well done"

70 Gessner 1558, 452 (swordfish), 485 (herring).

Gesnerus 73 (2016) 
(icon bene facta) while pointing out at the same time that it was missing one dorsal fin, while in another figure, a missing fin is attributed to the "carelessness (incuria)" of the painter. ${ }^{71}$ However, accuracy appears not to have been the prevailing criterion of selecting which figures should be made into a woodcut in the Historia animalium..$^{72}$ This is particularly marked in the case of images of Venetian origin. These were used even when Gessner is clear that Rondelet's images are better (melior) and the Venetian ones less accurate (minus accurate) or less exquisite (minus exquisitam) ${ }^{73}$ The most striking case is an image of a cuttlefish made in Venice, which shows the wrong number of legs (Rondelet's shows the correct number), a mistake attributed to the negligence of the artist (negligentia pictoris). ${ }^{74}$ The pictures painted in Venice appear to have different origins - some are described as "drawn for me", thus probably indicating that they were commissioned by Gessner when he was visiting Venice, while others are described as sent from a "friend". 75 This might point to some personal attachment Gessner had to images he had acquired himself while in Italy.

The Amsterdam album provides us with a rather rare opportunity of documenting a negative choice by Gessner; for example, there were three images that reached Gessner from Rome, but were not used by him in print. But such a negative choice does not necessarily indicate that he did not value these particular pictures. The three images represent the donsella (III C 22, 63) (fig. 15a), milvus lucerna (III C 22, 87) (fig. 15b), and mullus barbatus (III C 22,88 ) (fig. 8c). ${ }^{76}$ The latter two images show great similarities in style and colouring. Although Platter's annotation is very explicit in these two cases and says that they came "à Corn. Sittardo" and "à Cornel. Sittardo Roma", Gessner does not refer to either Rome or Sittardus or Horstius in the printed text concerning these particular fish (but he may do so under another heading, of course), while he uses very different images as illustrations. Perhaps Gessner simply did not like these particular drawings, but he may also have been hesitant about using them because he was uncertain which fish were

71 Gessner 1558, 39 and 709.

72 For the juxtaposition of varying qualities of images by Gessner, see further Kusukawa 2010, 323-327.

73 Gessner 1558, 114 and 434 (minus accurate), 128 and 491 (melior), 583 (minus exquisitam). We do not know whether there is a possible connection between these Venetian images in the Amsterdam album and the drawings of fish painted by a certain "master Plinio" and collected by the Venetian patrician Daniel Barbaro (1514-1570). Some of those were copied by Pierre Belon (in England, where Barbaro was ambassador) and later used by Belon in his works on fish. See Pinon 2002, 485 and 490.

74 Gessner 1558, 1024.

75 Gessner 1558, 553, 1224, 1237 (drawings made for him); 780, 943, 1223 (sent by a friend). For Gessner's visit to Venice, see Wellisch 1975, 159.

76 See on milvus and lucerne Gessner 1558, 588-591, on mullus Gessner 1558, 665-678. 


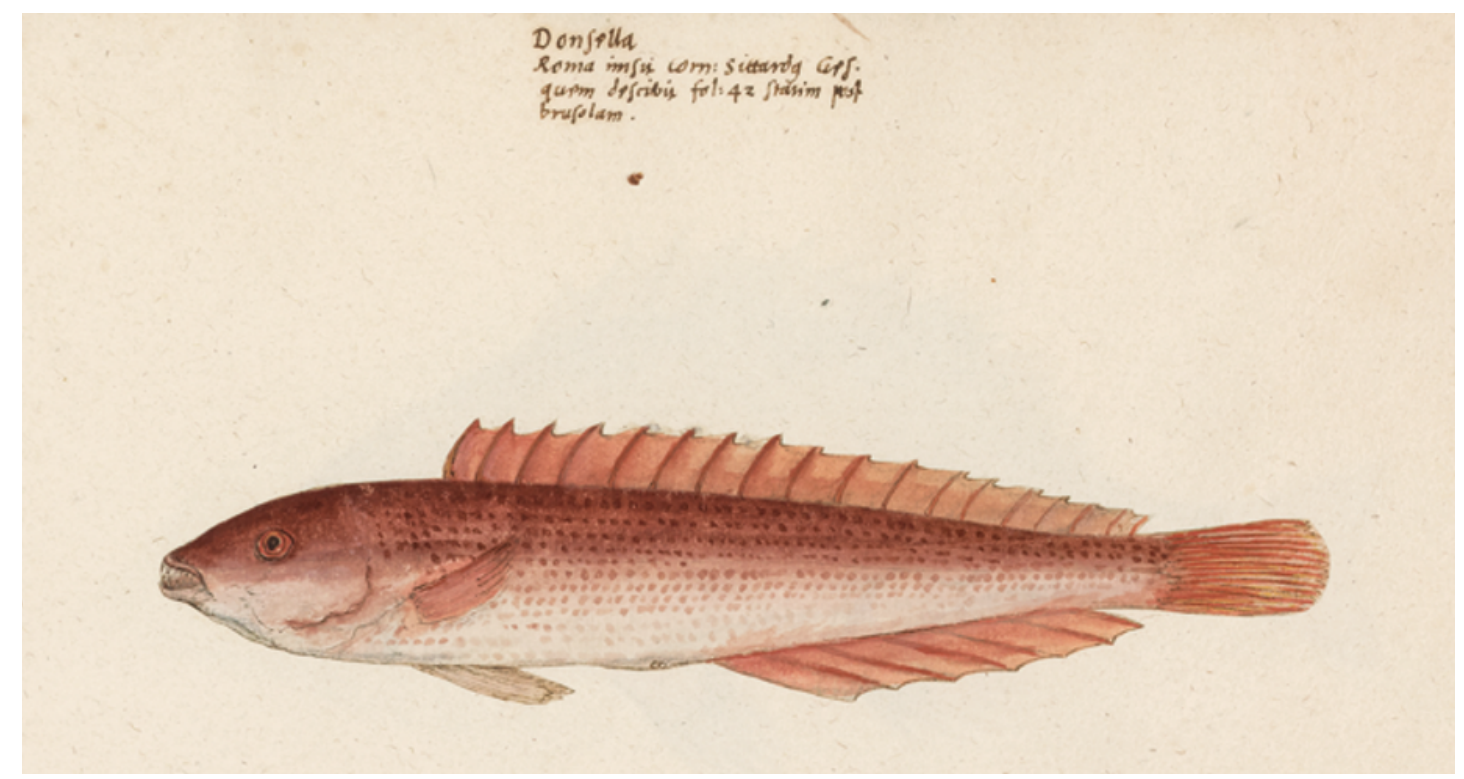

Fig. 15a: Donsella. Ms III C 22, 63. (Amsterdam University Library)

shown here, since he emphasizes that not only the mullus but also the milvus, cuculo and hirundo are red..$^{77}$ The case of the donsella has more to offer. In the annotation to the donsella in the Amsterdam album Platter writes: "Donsella. Cornelis Sittardus sent it from Rome to Gessner, he described it on fo. 42 immediately after the brusola". The Amsterdam drawing of the donsella shows a reddish and fairly unimpressive fish; many reddish dots suggest the pattern of the scales. Gessner has no separate chapter about the donsella, nor does he show the image, but he does mention the fish and Sittardus' image of it on p. 42 in his postscript to the section about the fish Alpheste. Here Gessner refers to an image of the donsella that he had once received from Sittardus and which showed the fish to be of a reddish colour with some yellow in the tail and the fins - which is exactly what we see on Sittardus' drawing in the Amsterdam album. ${ }^{78}$ Once more uncertainty concerning the identity of a depicted fish seems to be the main reason why Gessner decided not to use a particular image.

On the other hand, greater certainty concerning identification combined with a general sense of accuracy and aesthetic quality were reason for a pos-

77 Naturally, the presence of these images raises questions about Platter's information concerning Gessner's work and collection. Did Platter have special information about Gessner's work, or had he perhaps acquired more than just images from Gessner's legacy, perhaps even a manuscript of Gessner's works? Further research including an analysis of Platter's inventory (Suppellex) is needed before we can be certain that Platter knew more than Gessner tells the reader in print.

78 Ms III C 22, 63. "Roma misit Corn. Sittardus Ges. quem describit fo. 42 statim post brusolam". Cf. Gessner 1558, 42. 


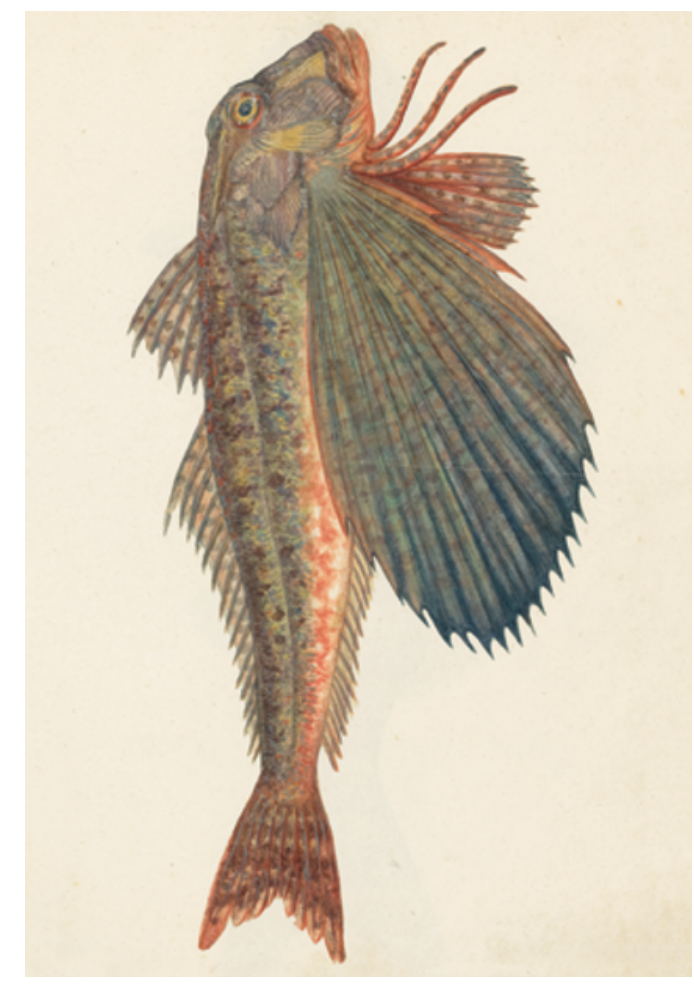

Fig. 15b: Milvus lucerna. Ms III C 22, 87. (Amsterdam University Library)

itive choice. In the text about the fish iulis, for instance, Gessner explains that he preferred to print his own image of the iulis rather than Rondelet's picture, because his own image was more elegant. He also criticizes Belon's image of the same species because it does not show the tip of the mouth well enough, although in other respects he find Belon's image superior to Rondelet's. ${ }^{79} \mathrm{He}$ continues:

When I showed the painting of the fish done in Venice as shown above to Gillius ${ }^{80}$, he told me that it was a iulis, and that he had been the first to identify it. I have one among the pictures of Corn. Sittardus which is rather different in colour but not in shape from the one shown above. Which shows its teeth with the mouth open, which was said by some to be called tinca marina. No doubt because that species of iulis is mainly green.

Since the Venetians called the iulis by the name donsella, and the donsella, tinca marina, brusola and iulis could easily be confused, Gessner may not

79 "Rondeletii figuram non posui, sed nostram eiusdem piscis, elegantius expressam. Bellonii pictura oris acumen non satis ostendit, variam vero illam medii corporis lineam similiter fere ut nostra, molto clarius quam Rondeletius monstrat", Gessner 1558, 549; "Cum Venetiis pictum piscem, quem supra exhibui, Gillio ostendissem, is statim iulidem esse me docuit, idemque se omnium primum observasse. Ex picturis Cor. Sittardi habeo non forma sed coloribus ab ea quam exhibui nonnihil differentem; quae et dentes ore aperto ostendit, tineam marinam ab aliquibus vocari adscriptum erat, nimirum quod magna ex parte viridi colore sit iulidis illa species", Gessner 1558, 550.

80 Petrus Gyllius, or Pierre Gilles (1490-1555), French naturalist and friend of Gessner. He was well informed about and published on French and Mediterranean fish, Gyllius 1533. He visited Venice, was in Rome in 1540, and spent several years in the Middle East. 
have been certain which image from Rome represented which species. ${ }^{81}$ In fact, looking back at Gessner's description of the beautiful stromataeus (or iulis or donsella) fish above (fig. 6b) we find that Gessner actually refers there to two images from Sittardus of which he only uses one:

We have shown here the picture that received in the past from Cornelius Sittardus together with other fish depicted at Rome (...) He also sent a picture of one which was one or two digitos longer than the one we show here. ${ }^{82}$

Although Gessner was not particularly consistent in his evaluation of the images themselves and used them in a pragmatic way, his choice to use certain images in his printed works or to refrain from using them appears to have been motivated by a mixture of aesthetic considerations and a conviction that the accuracy in the rendering of an animal was sufficient to help rather than hinder its identification. In the case of the pictures of the novacula, identification certainly seems to be the key point. Gessner first adopted the figure from Rondelet's book, but at a later stage, while still compiling the volume, he decided to include in the "addenda" section at the end of the volume a woodcut made after a drawing sent by Sittardus which could not be found at that time. ${ }^{83}$ There, he says that either image by Rondelet or Sittardus, if not accurate, should be sufficient for recognizing the fish, and furthermore points the reader to another "elegant" image in Salviani's book. ${ }^{84}$ The two woodcuts of the novacula are shown together in the Icones (1560). ${ }^{85}$ This seems to be a case where Gessner appears to be uncertain about the level of accuracy of the images, but believes that perhaps the two images together could be used for identification.

81 Gessner 1558, 549-50, quote on 550: "Cum Venetiis pictum piscem, quem supra exhibui, Gillio ostendissem, is statim iulidem esse me docuit, idemque se omnium primum observasse. Ex picturis Cor. Sittardi habeo non forma sed coloribus ab ea quam exhibui nonnihil differentem; quae et dentes ore aperto ostendit, tinca(m) marinam ab aliquibus vocari adscriptum erat, nimirum quod magna ex parte viridi colore sit iulidis illa species."

82 See also note 34 above. Gessner 1558, 1110: "A nobis posita pictura, quam a Cor. Sittardo cum aliis piscibus Romae depictis olim accepi, [...] De ea doctissimus Sittardus sic ad me scribebat: Hic piscis Fetolo vulgo dicitur, Romanis lampeca, [...] nec excedit hanc magnitudinem. Erat autem missa ab eo pictura, uno altero ve digito longior, quam a nobis hic proposita est."

83 Gessner 1558, 741, which copies the figure from Rondelet 1554/5, vol. 1, 146. Sittardus's image is at Gessner 1558, 1283. Sittardus's drawing is at Ms III C 22, 79 (top); a corresponding image is in Codex Kentmanus, 161v.

84 Gessner 1558, 1283: "Hic aliam a sculptore nostro iam prius elaboratam (ad picturam a Cor. Sittardo missam, sed quae tum nos subterfugerat,) damus. qui elegantiorem requirit, e Salviani libro petat. Nostra quidem haec, sicut et Rondeletij, si non satis accurata, ad piscis tamen cognitionem satisfecerit."

85 Gessner 1560b, 62. 


\section{Conclusion}

The fact that a considerable number of original sixteenth-century drawings of animals and plants has been (re-)discovered or (re-)identified in recent years is in itself the consequence of a strong revival of the interest in natural history, visual history and the history of science. Juggling with large numbers of images, investigating matches and half-matches, reversals and nonreversals, while inevitably working with only a part of the sources that existed in the sixteenth century, helps to at least partially reconstruct how images originated and circulated that had a lasting influence on European early natural science, and in some cases on a rather wider audience than the purely scientific one. The circulation investigated here between Rome, Zurich, Nuremberg, Meissen, Torgau, and Montpellier was only part of the far more wide-ranging circulation of images among European naturalists. Further research - including matching other images in the Amsterdam albums with European collections - will hopefully enable us to reconstruct other segments of that European circulation. Obviously, some of this circulation followed the paths and the networks of correspondence between naturalists in Europe that have so far been partially traced and investigated. But the exchanges between Horstius, Sittardus, Gessner, Kentmann and Rondelet show that some of these exchanges cannot be traced by means of correspondence alone - either because that is no longer extant, or because such exchanges were never mentioned in writing or were made through personal contact. Those exchanges of images can only be investigated, if at all, by means of visual similarity and through references in printed works.

The more we know about this kind of circulation, the clearer it becomes that the roles of collector and intermediary often coincided. With the possible exception of Sittardus, who mainly acted as intermediary, all of the men discussed here were researchers and collectors of images and naturalia as well as communicators, who exchanged and transmitted information in writing, orally, and visually via drawings and via the naturalia themselves. They all participated in the practice of collecting images, having them painted and copied (or doing this personally), and in sharing them, almost as a joint stock of visual knowledge. This is not to say that scholars and naturalists of the time had no sense of ownership of their images. Indeed, Rondelet's scathing and thinly veiled attack against both Belon and Salviani indicates that not acknowledging the source of image or information was tantamount to theft and extreme impropriety. ${ }^{86}$

86 Rondelet 1554/5, vol. 1, [5r], 423-424. 
The many different draughtsmen and painters from whom they commissioned these drawings are nearly always nameless: we may assume that quite a few of them were local painters and draughtsmen of the artisanal kind, who were called upon to portray a rare fish that had just been caught, or a nice item that captured the attention of a naturalist-collector at the fish market. Unless we are able to find out much more about the circles of such artisanal painters, or about the lives and acquaintances of collectors-naturalists such as Horstius, chances are slim that we will be able to identify such individual painters by anything else than their stylistic characteristics or to give them a name. On-going research in Bologna concerning multiple copies of Aldrovandi's naturalia is beginning to uncover a workshop (bottega) of painters who continued to produce copies of plant and animal drawings also after Aldrovandi's death in 1605 - presumably intended for a market. ${ }^{87}$ Stylistic comparison and analysis of the watercolours in the Amsterdam albums has only just begun, however, and a few of the fish images (though not those in the Horstius-Sittardus group) show promising stylistic similarities with the fish drawings in sixteenth-century albums in the Viennese collections and on frescoes in the Veneto that need to be explored further.

Multiple copying of original drawings seems to have occurred in midsixteenth-century Rome - possibly between Salviani and Horstius; almost certainly in the case of the copies of Horstius' own collection of drawings for Gessner and later for Kentmann. Such multiple original drawings were produced and used in the particular context of international information exchange among naturalists that itself was part of the commonly recognized research "project" to map the natural world and identify its species. It has been pointed out in a different context that manuscript copies of newsletters could have a quicker circulation and distribution than printed ones, and it might be worthwhile to investigate whether the circulation of original images of naturalia might have had similar advantages in this period and for this particular group of naturalists. ${ }^{88}$ Copying must have provided work for some local draughtsmen. It also indicates that there was a demand for such images on the part of European naturalists and not just on that of wealthy aristocratic collectors. Naturalists were rarely rich themselves, but some of them, such as Salviani, found patrons willing to subsidize their research and publications. Thus far, we know very little about the process of commissioning

87 Research presented by Giuseppe Olmi and Lucia Tongiorgi Tomasi at the conference "Ulisse Aldrovandi. Libri e immagini di storia naturale nella prima età moderna" (Bologna, Sept. 2015).

88 See Pieper 2000; Bouza 2001; and Bouza 1999. 
such images, the precise relations between patron, naturalist and painter, and their respective influences on the image itself.

Finally, our findings of almost identical originals - that is, multiple original drawings which closely resemble one another, sometimes are copies of each other, but always are original and more or less contemporary drawings raises questions about reproducibility by means of drawing rather than print. The recovery of more than one set of original drawings in itself already suggests that the notion of a unique "original image" (drawing, watercolour) may require further scrutiny, as do the notions of "original" and "copy" themselves. ${ }^{89}$ After all, these drawings are copies and originals at the same time. Seen within the context of research and information exchange by visual means we should perhaps regard these multiple original drawings as very close to the various copies made of prints that circulated. That would distance them from the category of "art" without pronouncing any judgment on their aesthetic qualities, and at the same time possibly help to cross an artificial barrier between mechanically reproduced print and original unique art, constructed on the basis of technological difference but translated into an epistemic distinction.

\section{Acknowledgements}

We would like to thank Elisa Andretta, Sabine Hackethal, Gillian Lewis, Peter Mason, Giuseppe Olmi, Laurent Pinon, Marrigje Rikken and the anonymous readers of this article for their suggestions and comments. Florike Egmond's research for this article was done as part of the NWOfunded projects Re-reading the Book of Nature and A New History of Fish, both at the University of Leiden. Sachiko Kusukawa thanks Trinity College, Cambridge, for financial support for obtaining the images and reproduction rights of images.

89 See the useful discussion in Alexander 1989. 


\section{Bibliography}

\section{Manuscript and archival sources}

Gessner-Platter albums: University Library Basel, Ms K i 2 (minerals-fossils-stones); Ms K i 1 (birds)

Gessner-Platter albums: University Library Amsterdam, Ms III C 22 (aquatic animals) and Ms III C 23 (fourfooted animals, insects, reptiles, amphibians)

Gessner, drawings of animals: Zentralbibliothek, Zurich, Manuscript Department Ms P 66, and Grafische Sammlung, Ehem. Varia Tiere I, 10.

Kentmann album: Ms Codex Kentmanus, Anna Amalia Bibliothek, Weimar

Lazarus Röting, Theatrum Naturae (1615), Museum für Naturkunde, Berlin

Archivio di Stato Roma (ASR), Ospedale Santa Maria della Consolazione, Inventory 52-53: Entrate e uscite del Camerlengo 1204 (1549); and Registri dei Mandati $802(1549)$

\section{Printed works}

Abeele, Baudouin van den, "Les albums ornithologiques de Jacques de Dalechamps, médecin et naturaliste à Lyon (1513-1588)", in: Archives internationales d'histoire des sciences 52 (2002) 3-45

Alexander, Jonathan J. G., "Facsimiles, copies, and variations: The relationship to the model in medieval and Renaissance European manuscripts", in: Retaining the original: Multiple originals, copies, and reproductions. Studies in the History of Art 20 (Hanover, London 1989) 61-72

Alveri, Gasparo, Roma in ogni stato, Parte seconda (Rome 1664)

Bosman-Jelgersma, Henriette, "Hoe Pieter van Foreest de geleerde Petrus Foreestus werd", in: H. Houtzager (ed.), Pieter van Foreest. Een Hollands medicus in de zestiende eeuw (Amsterdam 1989) 11-24

Bouza, Fernando, Comunicación, conocimiento y memoria en la España de los siglos XVI y XVII (Salamanca 1999)

Bouza, Fernando, Corre manuscritto. Una historia cultural del Siglo de Oro (Madrid 2001)

Bushnan, J. S., The Natural History of fishes, Particularly their structure and economical uses, II (Edinburgh 1840)

Céard, Jean, La Nature et les prodiges. l'insolite au XVI siècle (Geneva 1977)

Cordus, Valerius (ed. by Conrad Gessner), Annotationes in Pedacii Dioscorides Anazarbei De medica materia libros V (Strasbourg 1561)

Cordus, Valerius, Stirpium descriptionis liber quintus [...] De morbo et obitu Valerii Cordi, epistola Hieronymi Schreiberi Norimbergensi (Strasbourg 1563)

Cronenburgius Dessennius, Bernardus, De compositione medicamentorum (Frankfurt am Main 1555)

Daston, Lorraine, and Katherine Park, Wonders and the Order of Nature: 1150-1750 (New York 1998)

Delisle, Candice, "Accessing nature, circulating knowledge: Conrad Gessner's correspondence networks and his medical and naturalist practices", in: History of Universities 23 (2008) 35-58

Dürling, Richard J., "Conrad Gesner's Liber amicorum (1555-1565)”, Gesnerus 22 (1965) 134-159 
Dürling, Richard J., “Conrad Gessner's Briefwechsel”, in: R. Schmitz/F. Krafft (eds), Humanismus und Naturwissenschaften (Boppard am Rhein 1980) 101-111

Egmond, Florike, "A collection within a collection: Rediscovered animal drawings from the collections of Conrad Gessner and Felix Platter", in: Journal of the history of collections 25 (2013) 149-170

Esposito Aliano, Anna, "Le confraternite e gli ospedali di S. Maria in Portico, S. Maria delle Grazie e S. Maria della Consolazione a Roma (secc. XV-XVI)", in: Ricerche di storia sociale e religiosa 9 (1980) 145-172

Fischel, Angela, "Collections, images and form in sixteenth-century natural history", in: Intellectual History Review 20 (2010) 147-164

Fischel, Angela, Natur im Bild: Zeichnung und Naturerkenntnis bei Conrad Gessner und Ulisse Aldrovandi (Berlin 2009)

Forestus, Petrus, Observationum chirurgicarum libri quinque. Quorum de tumoribus praeter naturam (Frankfurt am Main 1610)

Forestus, Petrus, Opera Omnia (Frankfurt am Main 1634)

Gessner, Conrad, Historiae animalium Liber I, de quadrupedibus viviparis (Zurich 1551)

Gessner, Conrad, Historiae animalium Liber II, qui est de quadrupedibus oviparis (Zurich 1554)

Gessner, Conrad, Historiae animalium Liber IV, qui est de piscium et Aquatilium animantium natura (Zurich 1558)

Gessner, Conrad, Nomenclator aquatilium (Zurich 1560a)

Gessner, Conrad, Icones animalium quadrupedum viviparorum et oviparorum ( $\mathrm{Zu}$ rich $1560 b)$

Gessner, Conrad, Fischbuoch (Zurich 1563)

Gessner, Conrad, Epistolarum medicinalium [...] Liber Quartus (Wittenberg 1584)

Gillispie, Charles C. (ed.), Dictionary of Scientific Biography (16 vols, New York 1970-80)

Giovio, Paolo, Novocomensis Medici De Romanis Piscibus libellus ad Ludovicum Borbonium cardinalem, amplissimus, in aedibus F. Minitii Calvi (Rome 1524)

Givens, Jean, Karen Reeds, Alain Touwaide (eds), Visualizing medieval medicine and natural history, 1200-1550 (Aldershot 2006)

Glardon, Philippe, L'histoire naturelle au XVI siècle. Introduction, étude et édition critique de La nature et diversité des poissons de Pierre Belon (1555) (Geneva 2011)

Gmelig-Nijboer, Caroline Aleid, Conrad Gessner's "Historia Animalium”: An inventory of Renaissance zoology (Meppel 1977)

Gudger, E. W., "The five great naturalists of the sixteenth century: Rondelet, Salviani, Gesner and Aldrovandi: a chapter in the history of Ichthyology", in: Isis 2 (1934) 21-40

Gyllius, Petrus, Ex Aliani historia per Petrum Gyllium latini facti, itemque ex Porphyrio, Heliodoro, Oppiano, tum eodem Gyllio luculentis accessionibus aucti libri XVI. De ui et natura animalium. Eiusdem Gyllii Liber unus, De Gallicis et Latinis nominibus piscium (Lyon 1533)

Hackethal, Sabine, "Das THEATRUM NATURAE des Michael Rötenbeck. Unbekannte Naturstudien 100 Jahre nach Dürer", in: Ferdinand Damaschun et al. (eds), Klasse Ordnung Art. 200 Jahre Museum für Naturkunde, (Rangsdorf 2010) $70-75$ 
Helm, Johannes, Johannes Kentmann (Wiesbaden 1971)

Holthuis, Lipke B., "Original watercolours donated by Cornelius Sittardus to Conrad Gesner, and published by Gesner in his (1558-1670) works on aquatic animals", in: Zoologische Mededelingen 70 (1996) 169-196

Horstius, Gissibertus, De turpeto et thapsia (Rome 1544)

Huber, K., Felix Platters "Observationes": Studien zum frühneuzeitlichen Gesundheitswesen in Basel (Basel 2003)

Jennett, Seán (ed. and transl.), Beloved son Felix: The Journal of Felix Platter. A medical student in Montpellier in the sixteenth century (London 1961)

Kusukawa, Sachiko, "Image, text and 'Observatio': The Codex Kentmanus", in: Early Science and Medicine 14-4 (2009) 445-475

Kusukawa, Sachiko, "The sources of Gessner's pictures for the Historia animalium", in: Annals of Science 67 (2010) 303-328

Kusukawa, Sachiko, Picturing the book of nature: image, text, and argument in sixteenth-century human anatomy and medical botany (Chicago 2012)

Landolt, Elisabeth, "Materialen zu Felix Platter als Sammler und Kunstfreund", in: Basler Zeitschrift für Geschichte und Altertumskunde 72 (1972) 246-306

Leemann van Elck, Paul, Der Buchschmuck in Conrad Gessners Naturgeschichtlichen Werken (Bern 1935)

Lestringant, Frank, "Fortunes de la singularité à la Renaissance: le genre de l'Isolario", in: Studi francesi 28-3 (1984) 415-436

Leu, Urs B., "The Rediscovered Third Volume of Conrad Gessner's Historia plantarum”. (In press 2016)

Leu, Urs B., Raffael Keller, Sandra Weidmann (eds), Conrad Gessner's private library (Leiden 2008)

Lewis, Gillian, "The debt of John Ray and Martin Lister to Guillaume Rondelet of Montpellier", in: Notes and records of the Royal Society 66 (2012) 323-339

Lötscher, Valentin, Felix Platter und seine Familie (Basel 1975)

Lüthy, Christoph, Sven Dupre (eds), Silent Messengers: the circulation of material objects of knowledge in the early modern Low Countries (Münster 2011)

Melchior, Adam, Vitae Germanorum Medicorum (Heidelberg 1620)

Molinari, Alberto (ed.), Immagine e natura. L'immagine naturalistica nei codici e libri a stampa delle Biblioteche Estense e universitaria. Secoli XV-XVII (Modena 1984)

Münster, Ladislao, "L' ospedale di S. Maria della Consolazione in Roma e la sua importanza scientifico-didattica nei secoli 15.-17.", Atti del Primo Congresso europeo di storia ospitaliera, Reggio Emilia, 6-12 giugno 1960 (Reggio Emilia 1960) $876-886$

Olmi, Giuseppe, Lucia Tongiorgi Tomasi, Attilio Zanca (eds), Natura-Cultura. L'Interpretazione del Mondo Fisico nei Testi e nelle Immagin (Florence 2000)

Olson, Roberta M.J., Alexandra Mazzitelli, "The discovery of a cache of over 200 sixteenth-century avian watercolors. A missing chapter in the history of ornithological illustration", in: Master Drawings 45 (2007) 435-521

Palmer, Richard, "Medicine at the Papal Court in the Sixteenth Century", in: Vivian Nutton (ed.), Medicine at the courts of Europe, 1500-1837 (London 1990) 49-78

Parshall, Peter, "Imago contrafacta: Images and facts in the Northern Renaissance", in: Art History 16-4 (1993) 554-579 
Pieper, Renate, Die Vermittlung einer neuen Welt. Amerika im Nachrichtennetz des Habsburgischen Imperiums 1493-1598 (Mainz 2000)

Pinon, Laurent, "Clématite bleue contre poissons séchés: Sept lettres inédites d'Ippolito Salviani à Ulisse Aldrovandi", in: Mélanges de l'école française de Rome 114 (2002) 477-492

Pomata, Gianna, "Observation rising: Birth of an epistemic genre, 1500-1650", in: L. Daston/E. Lunbeck (eds), Histories of scientific observation (Chicago 2011) 45-80

Rondelet, Guillaume, Libri de piscibus marinis in quibus verae piscium effigies expressae sunt (2 vols, Lyon, 1554/5)

Rytz, Walter, Das Herbarium Felix Platters. Ein Beitrag zur Geschichte der Botanik des XVI Jahrhunderts (Basel 1933)

Salzmann, C., "Francesco Calzolari, der Erforscher der Flora des Monte Baldo, und seine Pflanzensendung an C. Gessner in Zürich", in: Gesnerus 16 (1959) 81-103

Scribner, Bob, "Ways of seeing in the age of Dürer", in: Dagmar Eichberger/Charles Zika (eds), Dürer and his culture (Cambridge 1998) 93-117

Turner, William, Avium praecipuarum quarum apud Plinium et Aristotelem mention est, brevis et succincta historia (Cologne 1544)

Wellisch, Hans, "Conrad Gessner: A bio-bibliography", Journal of the society of the bibliography of natural history 7-2 (1975) 151-247 